\title{
Petrology, Rank And Geochemical Evaluation Of Maastrichtian Coals From Se Nigeria: Implication For Petroleum Generation.
}

\author{
U.M. Uzoegbu ${ }^{1 *}$, I.A. Ekeleme ${ }^{2}$, J. Kus $^{3}$ and U.A. Uchebo ${ }^{4}$ \\ Geology Programme, Abubakar Tafawa Balewa University, P. M. B 0248, Bauchi, Nigeria. \\ Petroleum Trust and Development Fund, Chair, Department of Geology and Mining, University of Jos, PMB \\ 2084, Jos, Nigeria. \\ Organic Geochemistry/Organic Petrography Section, Federal Institutes for Geosciences and Natural \\ Resources, Postfach 51015, 30631, Hannover, Germany. \\ Geology Programme, Abubakar Tafawa Balewa University, PMB 0248, Bauchi, Nigeria.
}

\begin{abstract}
The Maastrichtian Mamu and Nsukka Formations in the Anambra Basin (SE Nigeria) consists of a cyclic succession of coals, carbonaceous shales, silty shales and siltstones interpreted as deltaic deposits. Subbituminous coals within these formations are distributed in a north-south trending belt from Enugu-Onyeama to Okaba in the north of the basin. Coals from these formations have been characterized by petrological and geochemical techniques. The aims of this study were to assess the quality of its organic matter, evaluate its thermal evolution and highlight its potential as a source rock. The total organic carbon (TOC) (67.21wt\%) of the coal constitutes that of a good source rock with gas-prone kerogen indicated by Rock-Eval $S_{2} / S_{3}$ (21.0). The high oxygen index (OI) (15.72 $\left.\mathrm{mgCO}_{2} \mathrm{~g}^{-1} \mathrm{TOC}\right)$ and $\mathrm{pr} / \mathrm{ph}$ (7.93) suggest deposition in a shallow marine environment. Maceral analyses showed that the coals are dominated by huminite with lesser amounts of liptinite and inertinite. Despite high liptinite contents in parts of the coals, the $n$-alkane distribution dominated by $n-C_{24}$ $-n-C_{31}$, an HI versus $T_{\max }$ diagram and atomic $H / C$ ratios of $0.80-0.90$ and $O / C$ ratios of 0.11-0.17 classify the organic matter in the coals as Type III kerogen. Vitrinite reflectance values $(\% R r)$ of 0.44 to $0.59 \%$ and $T_{\max }$ values between 414 and $432^{\circ} \mathrm{C}$ indicate that the coals are thermally immature to marginally mature with respect to petroleum generation. Hydrogen Index (HI) values for the studied samples range from 183.09 to $344.53 \mathrm{mg}$ $H C / g$ TOC and $S_{1}+S_{2}$ yields range from 120.5 to $242.04 \mathrm{mg} \mathrm{HC/g}$ rock, suggesting that the coals have gas and oil-generating potential. This thermal evolution is thought to account for its current hydrogen index (250.24 $\left.m g H C g^{-1} T O C\right)$. Generated petroleum may not have reached the threshold for hydrocarbon expulsion but a review of petroleum system elements in the basin will stimulate high prospects in the Anambra basin.
\end{abstract}

Key words: Organic matter, Kerogen type, Maturity, sub-bituminous coals, source rock, oil generation.

\section{Introduction}

The onshore sedimentary basins of Nigeria comprise Cretaceous and younger grabens which form part of a series of rift basins in central and West Africa. The Anambra Basin, a sub-basin in the Benue Trough, together with the neighbouring Abakaliki Basin to the east (Fig. 1), contains important coal measures which were discovered in the early part of the last century. Coal mining dates back to 1915 when sub-bituminous coals in the Mamu and Nsukka Formations (Maastrichtian, Danian: Fig. 2) were first exploited. Exploration in the coal basins also led to the discovery of extensive lignite deposits in the Oligocene-Miocene Ogwashi-Asaba Formations (Reyment, 1965). Initial mining of the sub-bituminous coals was concentrated in the Enugu area while other mines in the Owukpa and Okaba areas focused on the Mamu Formation with the discovery of smaller deposits around Ezimo, Ogboyaga and Inyi in the middle of the last century. Total sub-bituminous coal reserves in the north-south trending coal belt were assessed to be about 1.5 billion tons (Orajaka et al., 1990). Lignite deposits occur in numerous seams in an east-west belt which passes through Ihioma and Azagba Ogwashi to the SW of the coal belt (Fig. 1). Lignites reserves were estimated to total about 300 million tons but are largely unexploited (Orajaka et al., 1990). Subbituminous coal production, mainly in the Enugu area, reached an annual output of ca. 700,000 tons in the 1980s (Orajaka et al., 1990), but has since declined until recently, when efforts to revive it have been proposed by the Nigerian Government. This has encouraged detailed studies of the geology and physical and chemical characteristics of the coals.

The Anambra Basin is bounded to the south by the northern portion of the Niger Delta petroleum province (Fig. 1). Eneogwe and Ekundayo (2003) identified three oil families (A, B, C) in the NW Niger Delta. Oils in family "C" were generated from source rocks with abundant terrestrial organic matter (OM), while family "B" oils were derived from source rocks with mixed terrestrial and marine OM. The petroleum system in the northern portion of the Niger Delta contains light, waxy oils sourced mainly from land plant derived OM disseminated throughout the Eocene source rock units (Bustin, 1988; Ekeweozor and Daukoru, 1994). Furthermore, onshore in the rift complex, commercial hydrocarbon accumulations have been discovered to the 
north of the Benue Trough in Chad and the Sudan, and gas and oil shows have also been reported in Niger (Obaje et al., 2004). As a part of an on-going study of the evolution of the Nigerian coal basins and the burial histories of the Cretaceous-Tertiary sedimentary succession, we have carried out detailed petrographic analyses of 87 coal samples collected during field work between 2004 and 2006. Samples came from the EnuguOnyeama, Okpara, Ezimo and Okaba mines.

In this paper we assess coals from four regions in the Anambra Basin (Fig. 1), describing coals in terms of petrography (macerals, petroleum content), rank (i.e. random per cent vitrinite reflectance in oil $\left(\% R_{0}\right)$ and Rock-Eval 6 pyrolysis properties (e.g maximum temperature $\left(\mathrm{T}_{\max }\right.$ ), total organic carbon (TOC), free oil content $\left(\mathrm{S}_{1}\right)$ and hydrocarbon content $\left(\mathrm{S}_{2}\right)$. The samples showed good evidence for the presence of liquid hydrocarbons associated with both maceral groups and authigenic mineral matter. The purpose of this paper is to ascertain their organic matter source input, maturity and petroleum generation potentials.

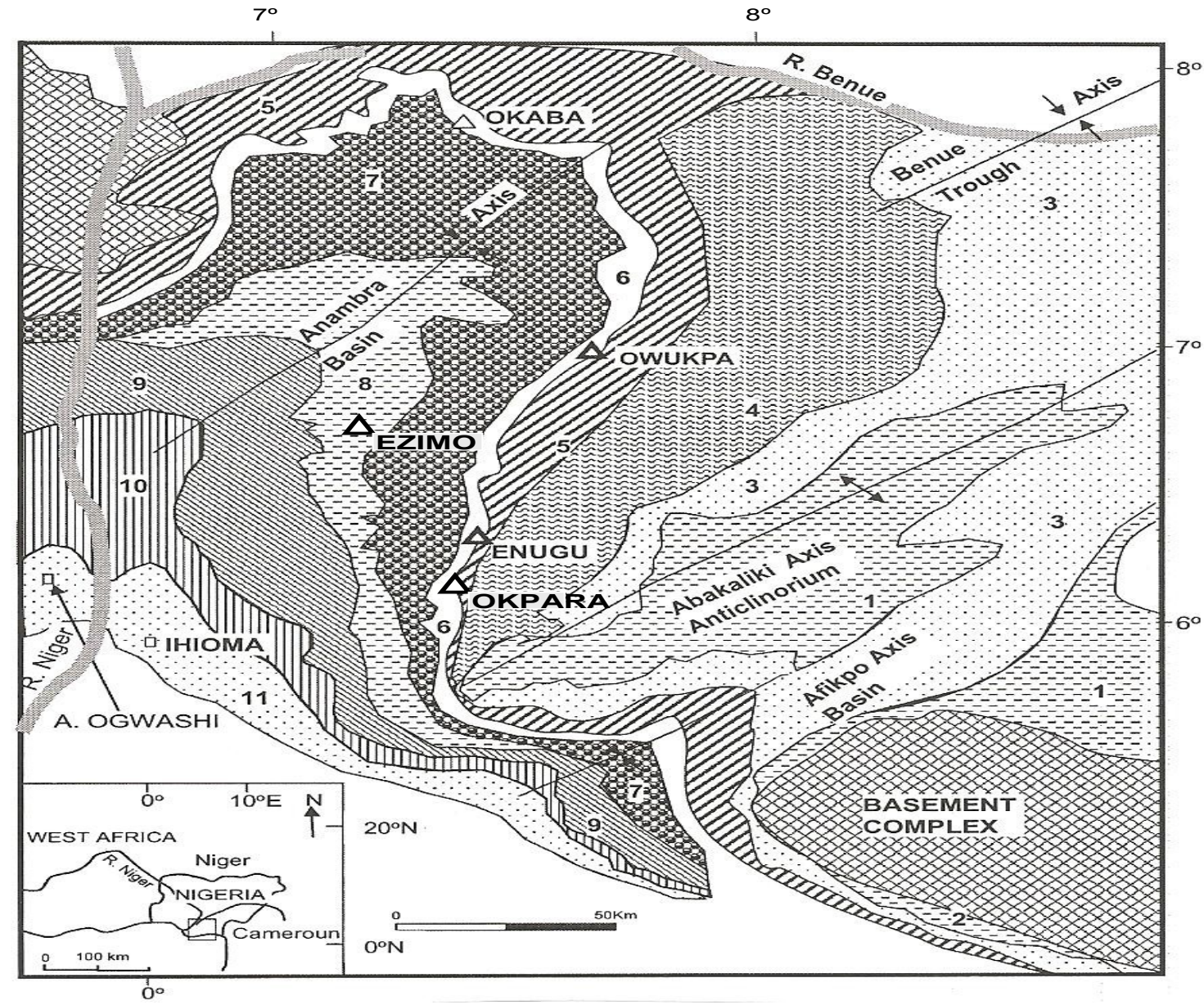

Fig. 1: Generalised geological map of the SE Nigeria (boxed areas of inset) showing the location of the coal deposits. Numbers indicate Cretaceous and Tertiary formations 1. Asu River Group; 2. Odikpani

Formation; 3. Eze-Aku Shale; 4. Awgu Shale; 5. Enugu/Nkporo Shale; 6. Mamu Formation; 7. Ajali Sandstone; 8. Nsukka Formation; 9. Imo Shale; 10. Ameki Formation and 11. Ogwashi-Asaba Formation (modified from Akande et al., 2007).

\section{Regional Stratigraphic Setting}

Sub-bituminous coals are restricted to the Maastrichtian Mamu and Nsukka Formations which crops out in long narrow ridges in the NE-SW trending Anambra Basin (Fig.1). The Mamu and Nsukka Formations consist of alternating sandstones, sandy shales and mudstones with interbedded coal seams. The formation is underlain by the Campanian Enugu/Nkporo Shales (lateral equivalents), and overlain by the Ajali Sandstone (Middle Maastrichtian) and Nsukka Formation (Upper Maastrichtian to Danian) (Fig. 2). Five sedimentary units are recognized in the Mamu Formation in the Enugu area, where the thickest exposed section (approximately 80 m) occurs (Simpsons, 1954; Reyment, 1965). From the base, the units consist of (i) a basal shale or sandy shale, (ii) sandstones with occasional shale beds, (iii) carbonaceous shales, (iv) coals and (v) sandy shales. The Nsukka Formation has well exposed section at Iyinzu in Ezimo area with thickness of about $55 \mathrm{~m}$. The succession is paralic as demonstrated by the alternating marine and Nigeria (Short and Stauble, 1967; Hogue, 1977; Agagu, 1978). Sediments of the third marine cycle were mainly deposited in Campanian - Maastrichtian 
times in the Anambra and Afikpo Basins (Fig.1). These two post-Santonian basins were formed as successors to the Benue Trough, where deposition of the first and second marine depositional cycles took place in Albian Santonian times (Figs 1 and 2). The third-cycle sediments were deposited during the initial growth of the protoNiger Delta in the Late Cretaceous (Allen, 1965; Short and Stauble, 1967). An Early Paleocene transgression led to the termination of the proto-Niger Delta and the deposition of Imo Shale, which was succeeded by the regressive phases of the Ameki and Ogwashi Asaba Formations.

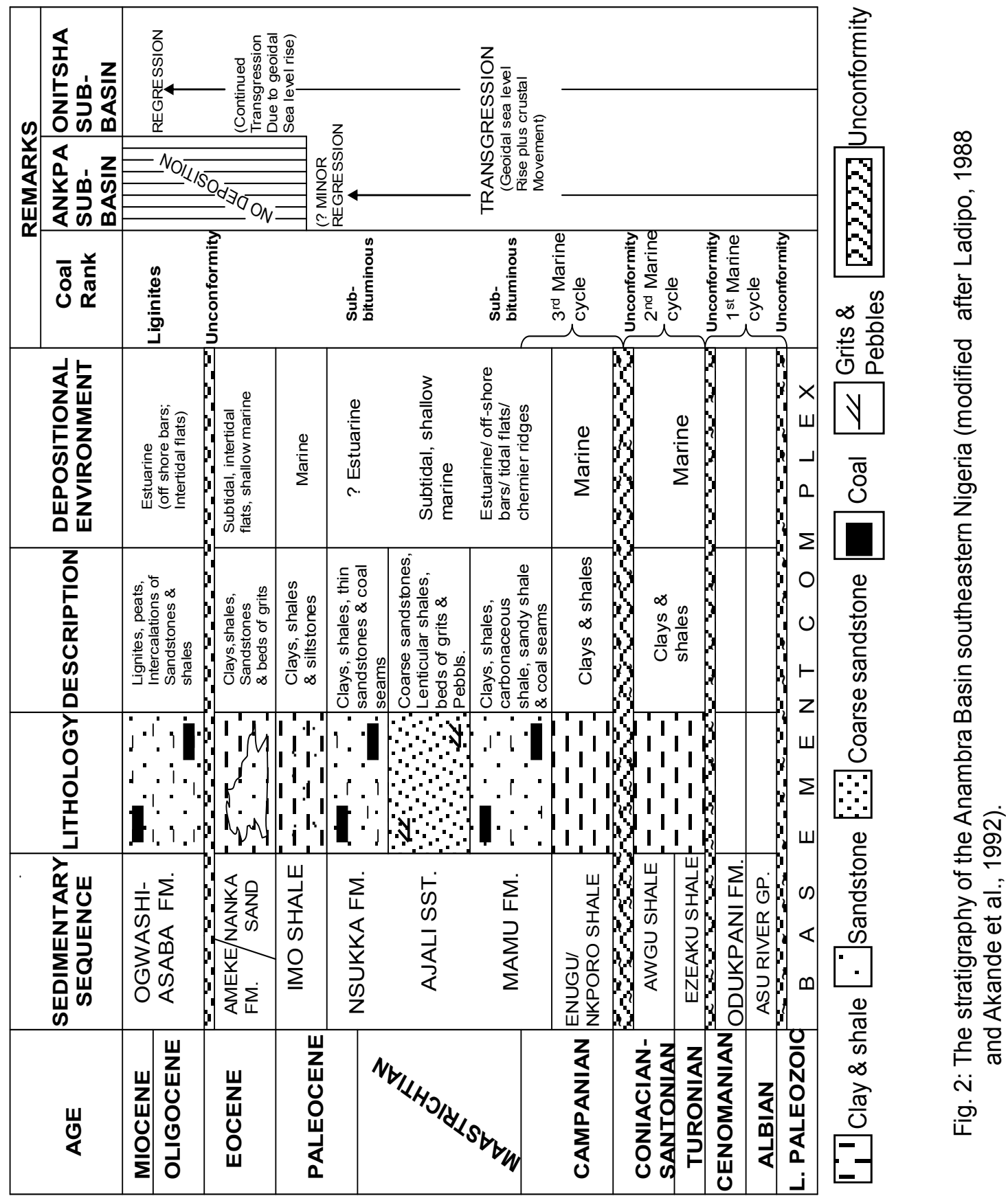




\begin{tabular}{|c|c|c|c|c|}
\hline AGE & FORMATION & 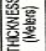 & $\begin{array}{l}\text { ITHOLOGKC } \\
\text { SECTION }\end{array}$ & DESCRIPTION \\
\hline$\frac{2}{4}$ & 39. & 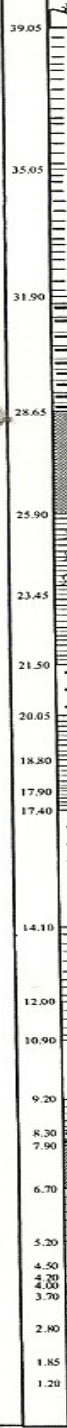 & $\begin{array}{l}\mid \\
\end{array}$ & 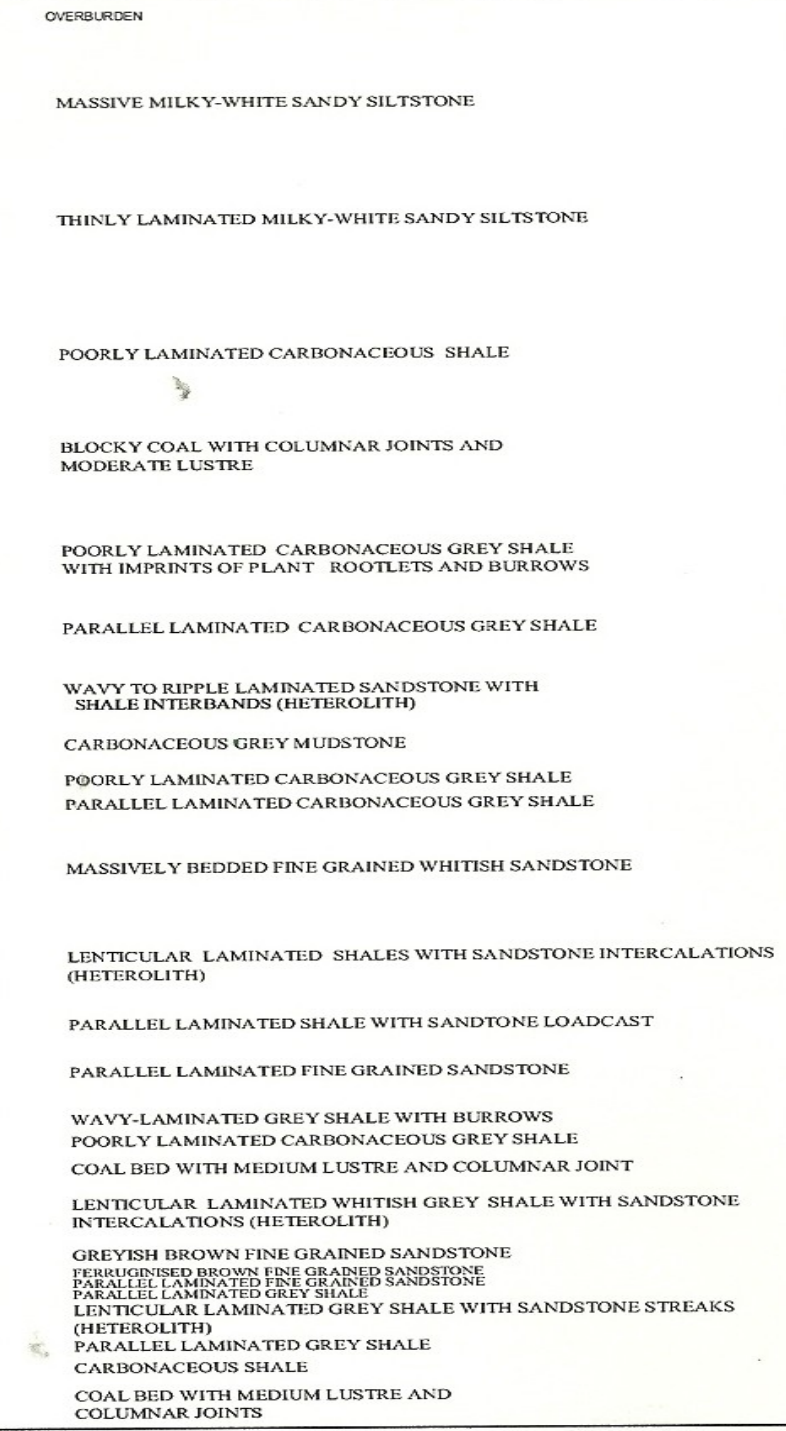 \\
\hline
\end{tabular}

Fig. 3. Sedimentary succession at the Enugu-Onyeama Mine

\section{Lithostratigraphy}

Sections through the Mamu Formation occur at the Enugu-Onyeama, Owukpa and Okaba coal mines (Figs 3, 4, 5). In general, the coal-bearing sections in these locations consist of cyclic successions of coal, carbonaceous shales, heteroliths (sandy shales and shaly sandstones), siltstones and bioturbated sandstones. The cyclothems are well exposed at the Onyeama section (Fig. 3), and are interpreted as deposits typical of a deltaic setting. At Onyeama (Fig. 3), the exposed succession shows a basal coal seam $1.2 \mathrm{~m}$ thick, overlain by a carbonaceous and parallel laminated grey shale. This is overlain by a heterolithic unit of grey shale with sandstone streaks, which grades upward into fine-grained sandstones. Two similar successions follow above in the $39.9 \mathrm{~m}$ thick section which includes three coal seams. The middle unit starts with a $1.2 \mathrm{~m}$ thick coal seam and contains three thick sandstone beds overlain by carbonaceous grey shales. The third $2.75 \mathrm{~m}$ thick coal seam occurs above. Siltstone beds cap the section. 


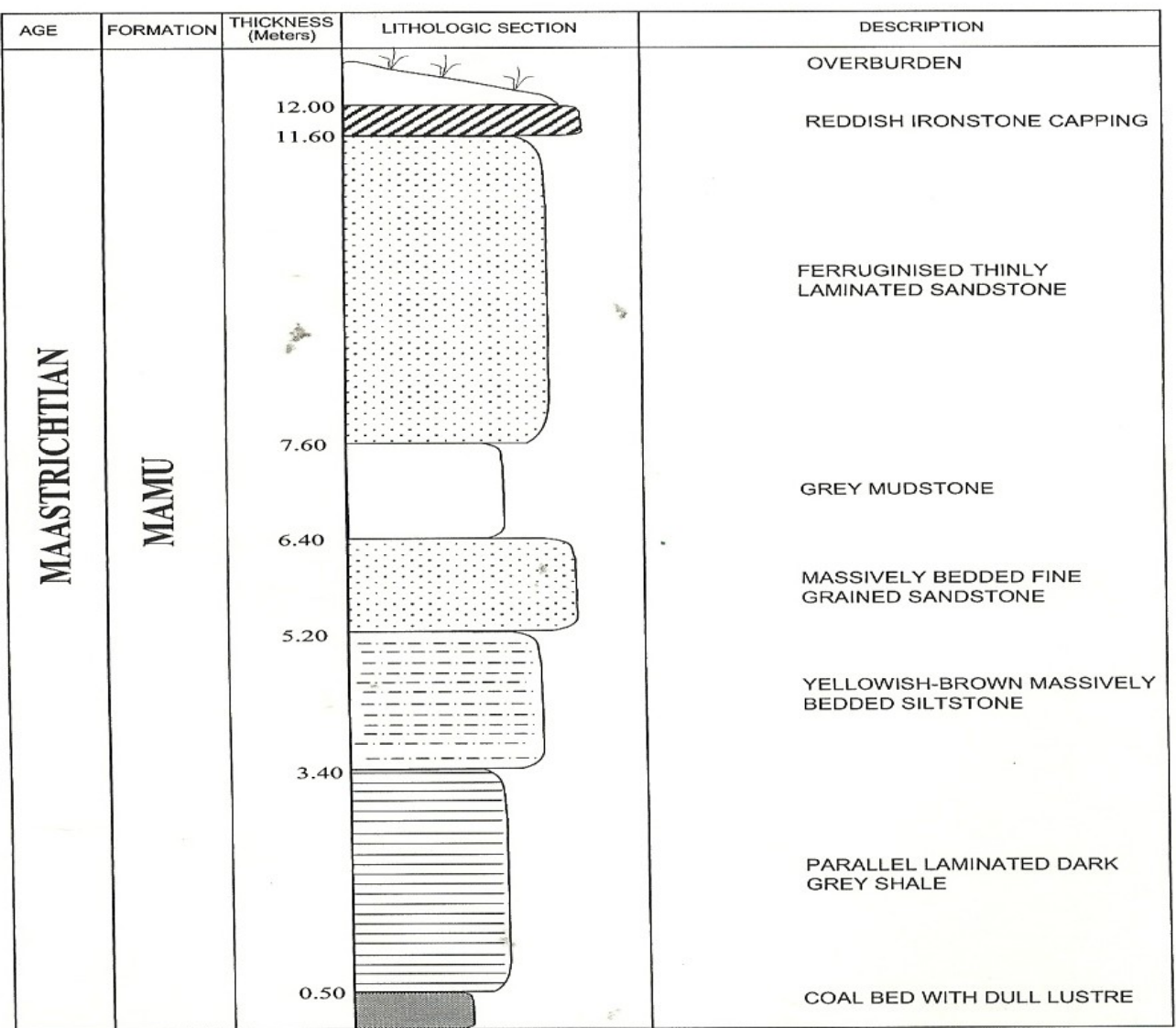

Fig. 4. Sedimentary succession at the Okaba Mine.

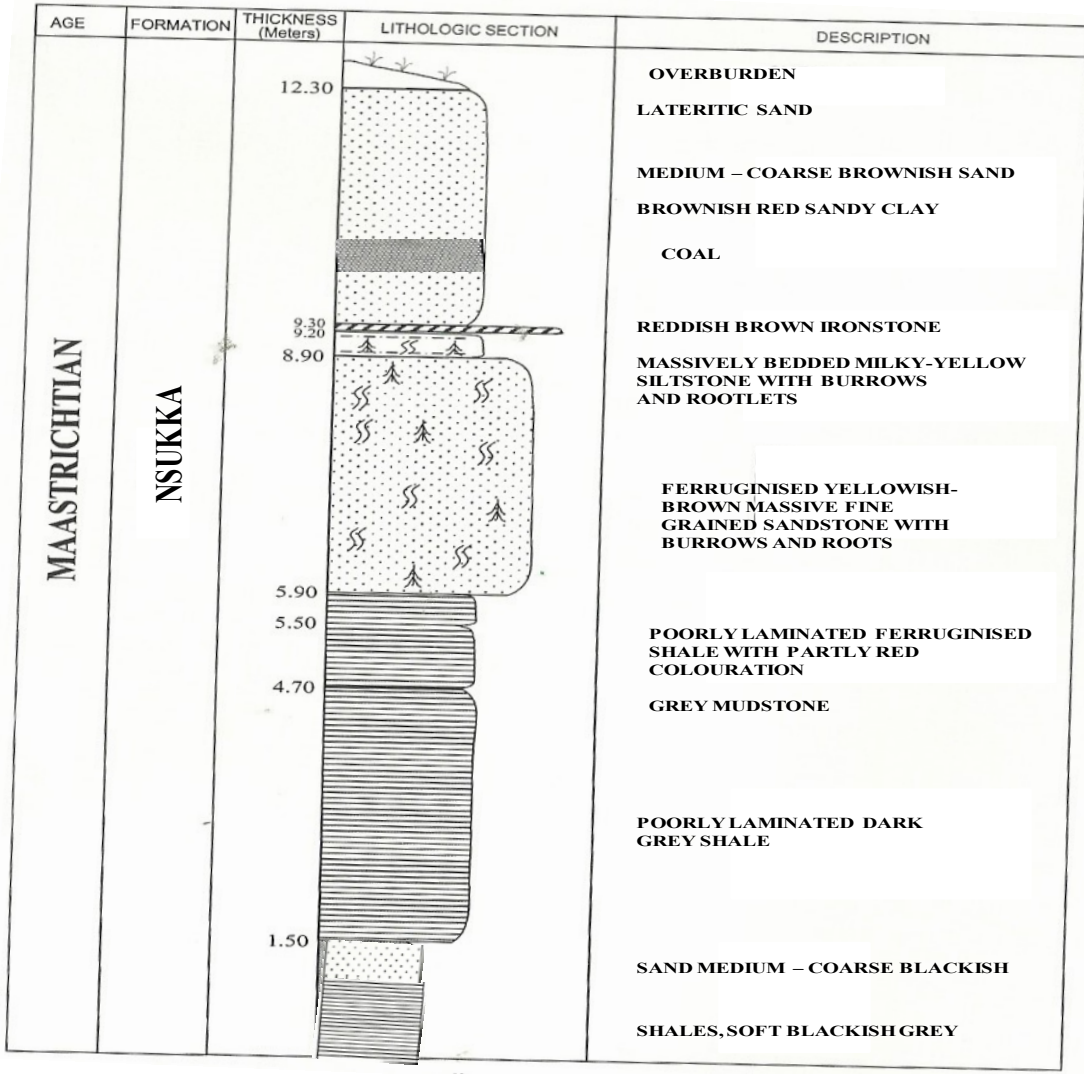

Fig. 5. Sedimentary succession at the Ezimo Mine. 


\section{Materials And Methods}

Lignites and sub-bituminous coals are widely distributed within the "coal measures" of the Maastrichitian Mamu and Nsukka formations to Miocene Ogwashi-Asaba Formations in the Lower Benue Trough (Akande et al., 1992). The coal deposits in the Lower Benue Trough occur mainly in the Enugu province where four mines: Iva valley, Onyeama, Okpara and Ribadu (Fig. 1) are being worked by the Nigerian Coal Corporation. Other coal deposits that are being worked in this area include those at Okaba, Owukpa, Ogboyaga and Ezimo; all found within the Mamu and Nsukka Formations.

A total of 87 coal samples were subjected to laboratory analyses, the samples were reshaped using a rotating steel cutter to eliminate surface that could be affected by alteration. Chips were cut from the samples and dried in an oven at $105^{\circ} \mathrm{C}$ for 24 hours. Chips cut perpendicular to bedding were embedded in epoxy and polished following the procedures of Taylor et al. (1998) to yield polished blocks for reflectance and fluorescence studies using scan electronic microscope. Another portion of the dried sample was pulverized in a rotating disc mill to yield about $50 \mathrm{~g}$ of sample for analytical geochemistry. The total organic carbon (TOC) and inorganic carbon (TIC) contents were determined using Leco CS 200 carbon analyzer by combustion of $100 \mathrm{mg}$ of sample up to $1600^{\circ} \mathrm{C}$, with a thermal gradient of $160^{\circ} \mathrm{C} \mathrm{min}^{-1}$; the resulting $\mathrm{CO}_{2}$ was quantified by an Infrared detector.

The sample with known TOC was analyzed using a Rock-Eval 6, yielding parameters commonly used in source rock characterization, flame ionization detection (FID) for hydrocarbons thermal conductivity detection (TCD) for $\mathrm{CO}_{2}$. One milligram of bulk powder sample was added to $200 \mathrm{mg}$ of $\mathrm{KBr}$ and the mixture homogenized using a pestle in an agate mortar. Pressing the mixture using a load of $10 \mathrm{t}$ yielded a pellet for Fourier Transform Infrared (FT-IR) Spectroscopy using a Nicolet Bench 505P Spectrometer, with sample absorbance monitored using 256 scans with resolution of $4 \mathrm{~cm}^{-1}$ from a wave-number of $4000-400 \mathrm{~cm}^{-1}$. About $10 \mathrm{~g}$ of the sample was subjected to sohxlett extraction using a solvent mixture of acetone, chloroform and methanol (47: 30: $23 \mathrm{v} / \mathrm{v}$ ) at $60^{\circ} \mathrm{C}$ for 24 hours to extract the soluble organic matter. The extract was concentrated by evaporation to dryness using a rotating vapour evaporator at $250 \mathrm{mb}$. The extract was transferred to an $8 \mathrm{ml}$ vial using the same solvent mixture and allowed to evaporate to dryness in a vented hood. The dried extract was fractionated by silica gel column chromatography with a column prepared using $2 \mathrm{~g}$ of baker silica gel calcined at $200^{\circ} \mathrm{C}$ for 24 hours to yield six fractions ranging from saturate to polar.

The saturate fraction was subjected to urea adduction to separate isoprenoids from $n$-alkanes and subjected to gas chromatography-mass spectrometry (GC-MS) using a CE 5980 GC coupled to an HP Finnigan 8222 MS held at $80^{\circ} \mathrm{C}$ for three minutes and raised to $310^{\circ} \mathrm{C}$ at $3^{\circ} \mathrm{C} \mathrm{min}^{-1}$ and held isothermally for 10 minutes in order to assess some molecular parameters used in source rock characterization.

\section{Organic petrography}

\section{Results}

The coal samples from the Onyeama, Okpara, Ezimo and Okaba mines in general are dominated by huminite with lesser contents of inertinite and liptinite (Table 1). These coals are duroclaritic in nature (Fig. 6). The macerals are not uniformly distributed and their proportions vary within individual seams. Samples from the Onyeama seams contain large amounts of huminite $(73.57-89.64$ vol. $\%$; mean $=78.81$ vol. $\%)$, low contents of inertinite $(2.61-16.30 \mathrm{vol} . \%$; mean $=9.46 \mathrm{vol} . \%)$ and generally low contents of liptinite $(5.50-13.81 \mathrm{vol} . \%$; mean $=10.01$ vol. $\%$ ). 


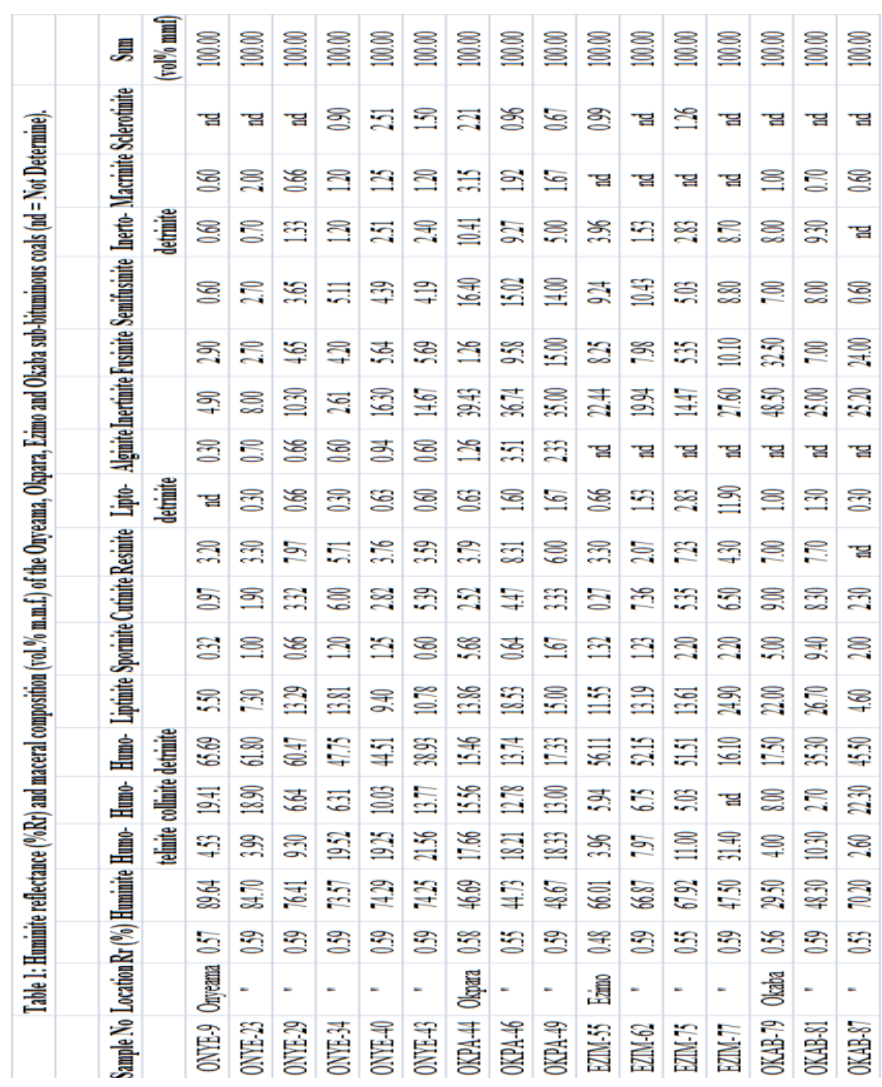

The huminite is predominantly composed of detrohuminite (attrinite and densinite) and telohuminite (especially ulminite). The inertinite consists mainly of fusinite, inertodetrinite and sclerotinite, whereas liptinite macerals are mostly sporinite, cutinite, resinite and rarely alginite in decreasing order of abundance (Fig. 6). In the Okpara mine, samples from the seam are dominated by huminite $(44.73-48.67$ vol.\%; mean $=46.70$ vol.\%), principally detrohuminite. The inertinite content varies from $35.0-39.43$ vol. $\%$ (mean $=37.06$ vol. $\%$ ), whereas the liptinite content is high $(13.86-18.53 \mathrm{vol} . \%$; mean $=15.80 \mathrm{vol} . \%)$. The liptinite consists principally of

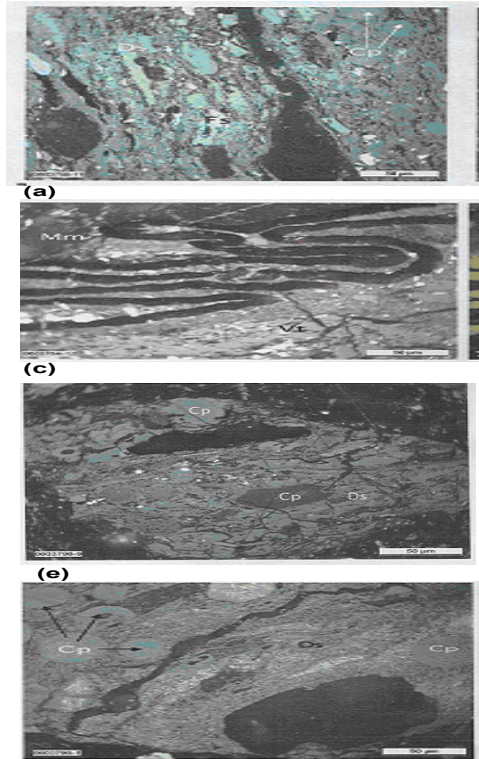

(g)
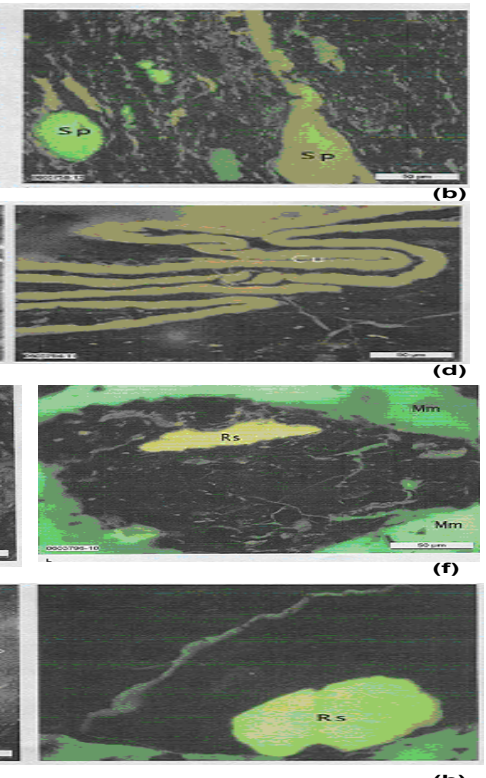

Fig. 6: Photomicrographs of samples viewed under white light (left side) and fluorescence light under ultraviolet excitation (right side). (a-b) ONYE-43: Sporinite macerals in a matrix of attrinite and inertodetrinite. Sporinite display orange and brownish fluorescence while inertodetrinite does not fluoresce. (c-d) OKPA-49: Cutinite macerals in a matrix of vitrodetrinite and inertodetinite. Cutinite display brown fluorescence. (e-f) OKAB-81: Resinite macerals associated with corpocollinite in a 
matrix of vitrodetrinite. Resinite display yellow fluorescence. (g-h) EZIM-75: Same as (e-f) though from different sample field.

sporinite, resinite, cutinite and liptodetrinite (Fig. 6). Samples from the Ezimo seam show an increasing content of huminite $(47.50-67.92 \mathrm{vol} . \%$; mean $=62.08 \mathrm{vol} . \%)$. The inertinite content also increases from $14.47-27.60$ vol. $\%($ mean $=21.11$ vol. $\%)$, whereas the liptinite content decreases $(11.55-24.90$ vol. $\%$, mean $=15.81$ vol. $\%)$. At Okaba, samples from the coal seam have a high content of huminite (70.2 vol.\%), principally detrohuminite and gelohuminite (Fig. 6). The inertinite content is quite high (48.5 vol.\%), whereas the liptinite content is low (4.6 vol.\%). The liptinite is mainly composed of resinite. In samples from the top part of seam, the coal is characterized by varying amounts of huminite $(29.5-70.2$ vol.\%; mean $=49.33$ vol. $\%$ ), a higher content of inertinite $(25.0-48.5 \mathrm{vol} . \%$; mean $=32.90 \mathrm{vol} . \%)$, and a low to moderate content of liptinite (4.6-26.7 vol.\%; mean $=17.8$ vol. $\%$ ). Maceral compositions and distributions in coals from the Onyeama and Okaba seams are similar with respect to huminite and inertinite. High contents of huminite occur throughout the seams but increasing contents of inertinite occur towards the Okpara mine. Conversely, high contents of

Table 2: Maceral and vitrinite \% Ro data for coals from the Anambra Basin southeastern Nigeria.

\begin{tabular}{|c|c|c|c|c|c|c|c|c|}
\hline Sample & Locality & Lithology & Formation & $\mathrm{H}$ & $\mathrm{L}$ & I & MM & $\% \mathrm{R}_{\text {. }}$ \\
\hline Name & & & \multicolumn{6}{|c|}{ vol. \% } \\
\hline ONYE & Onyeama & coal & Mamu & 79 & 10 & 9 & 2 & 0.59 \\
\hline OKPA & Okpara & " & Mamu & 47 & 14 & 36 & 3 & 0.57 \\
\hline EZIM & Ezimo & , & Nsukka & 62 & 16 & 21 & 1 & 0.58 \\
\hline OKAB & Okaba & , & Mamu & 49 & 18.5 & 33 & 0.5 & 0.56 \\
\hline
\end{tabular}

Table 3: Rock-Eval pyrolysis data for samples from Cretaceous formations from the Anambra Basin.

\begin{tabular}{|c|c|c|c|c|c|c|c|c|c|c|c|c|}
\hline $\begin{array}{c}\text { Sample } \\
\text { Name }\end{array}$ & $\begin{array}{c}\text { Sample } \\
\text { Type }\end{array}$ & Locality & $\mathbf{F M}$ & Lithology & S1 mg/g & S2mg/g & S3 mg/g & TOC (\%) & TS (\%) & $\mathbf{T}_{\max }\left({ }^{\circ} \mathbf{C}\right)$ & $\underset{\text { HOI }}{\text { mgS2/g }}$ & $\underset{\text { TOC }}{\text { OI }}$ \\
\hline ONYE-1 & $\underset{\text { Pit }}{\text { Mining }}$ & Onyeama & Mamu & Coal & 1.31 & 163.06 & 501 & 61.30 & 0.56 & 427 & 266.00 & 8.17 \\
\hline ONYE- 2 & " & " & " & " od & 1.46 & 185.45 & 6.30 & 71.40 & 1.17 & 428 & 259.73 & 8.82 \\
\hline ONYE-3 & $"$ & $"$ & $"$ & $"$ & 1.16 & 170.01 & 5.91 & 61.75 & 1.02 & 428 & 275.32 & 9.57 \\
\hline ONYE-4 & $"$ & $"$ & $"$ & $"$ & 1.54 & 195.20 & 7.11 & 76.65 & 0.84 & 426 & 254.66 & 9.28 \\
\hline ONYE-5 & $"$ & $"$ & $"$ & $"$ & 1.29 & 171.01 & 5.90 & 63.10 & 0.86 & 429 & 271.01 & 9.35 \\
\hline ONYE-6 & $"$ & $"$ & $"$ & $"$ & 1.89 & 213.73 & 6.03 & 75.65 & 0.95 & 428 & 282.52 & 7.97 \\
\hline ONYE-7 & $"$ & $"$ & $"$ & $"$ & 1.22 & 176.97 & 5.33 & 66.35 & 0.69 & 431 & 266.72 & 8.03 \\
\hline ONYE-8 & $"$ & $"$ & $"$ & $"$ & 1.92 & 198.69 & 5.32 & 72.55 & 1.04 & 429 & 273.87 & 7.33 \\
\hline ONYE-9 & " & $"$ & $"$ & $"$ & 0.61 & 116.41 & 4.93 & 44.40 & 0.74 & 429 & 262.18 & 11.10 \\
\hline ONYE-10 & $"$ & $"$ & $"$ & $"$ & 2.05 & 204.58 & 5.59 & 75.05 & 0.58 & 428 & 272.59 & 7.45 \\
\hline ONYE-11 & $"$ & $"$ & $"$ & $"$ & 1.07 & 154.58 & 5.03 & 55.55 & 0.90 & 429 & 278.27 & 9.05 \\
\hline ONYE-12 & $"$ & $"$ & $"$ & $"$ & 1.47 & 182.93 & 5.46 & 63.50 & 0.94 & 428 & 288.08 & 8.60 \\
\hline ONYE-13 & $"$ & $"$ & $"$ & $"$ & 1.63 & 175.90 & 5.82 & 63.30 & 0.60 & 428 & 277.88 & 9.19 \\
\hline ONYE-14 & $"$ & $"$ & $"$ & $"$ & 1.21 & 166.98 & 6.11 & 60.40 & 0.90 & 429 & 276.46 & 10.12 \\
\hline ONYE-15 & $"$ & $"$ & $"$ & $"$ & 1.41 & 184.53 & 5.42 & 65.25 & 0.98 & 429 & 282.80 & 8.31 \\
\hline ONYE-16 & $"$ & $"$ & $"$ & $"$ & 1.54 & 214.42 & 5.96 & 77.05 & 0.93 & 427 & 278.29 & 7.74 \\
\hline ONYE-17 & $"$ & $"$ & $"$ & $"$ & 1.38 & 181.77 & 5.25 & 64.75 & 0.88 & 430 & 280.73 & 8.11 \\
\hline ONYE-18 & $"$ & $"$ & $"$ & $"$ & 1.55 & 184.50 & 6.01 & 71.50 & 0.91 & 427 & 258.04 & 8.41 \\
\hline ONYE-19 & $"$ & $"$ & $"$ & $"$ & 1.51 & 188.80 & 5.64 & 54.80 & 0.88 & 428 & 344.53 & 10.29 \\
\hline ONYE-2O & $"$ & $"$ & $"$ & $"$ & 1.83 & 214.00 & 5.76 & 72.00 & 0.80 & 427 & 297.22 & 8.00 \\
\hline ONYE-21 & $"$ & $"$ & $"$ & $"$ & 1.19 & 181.16 & 5.71 & 65.35 & 0.78 & 429 & 277.21 & 8.74 \\
\hline ONYE-22 & $"$ & $"$ & $"$ & $"$ & 1.79 & 206.26 & 6.30 & 74.65 & 0.82 & 427 & 276.30 & 8.44 \\
\hline ONYE-23 & $"$ & $"$ & $"$ & $"$ & 0.26 & 42.78 & 2.77 & 17.80 & 0.47 & 430 & 240.34 & 15.56 \\
\hline ONYE-24 & $"$ & $"$ & $"$ & $"$ & 1.33 & 179.84 & 6.01 & 64.40 & 0.90 & 429 & 279.25 & 9.33 \\
\hline ONYE-25 & $"$ & $"$ & $"$ & $"$ & 0.93 & 167.09 & 6.74 & 69.30 & 0.88 & 429 & 241.11 & 9.73 \\
\hline ONYE-26 & $"$ & $"$ & $"$ & $"$ & 1.69 & 197.16 & 5.69 & 68.25 & 0.72 & 428 & 288.88 & 8.34 \\
\hline ONYE-27 & $"$ & $"$ & $"$ & $"$ & 1.09 & 164.37 & 5.83 & 60.05 & 0.97 & 429 & 273.72 & 9.71 \\
\hline ONYE-28 & $"$ & $"$ & $"$ & $"$ & 1.06 & 170.09 & 5.73 & 60.70 & 0.87 & 431 & 280.21 & 9.44 \\
\hline ONYE-29 & $"$ & $"$ & $"$ & $"$ & 1.02 & 166.63 & 5.11 & 62.25 & 0.69 & 432 & 267.68 & 8.21 \\
\hline ONYE-30 & $"$ & $"$ & $"$ & $"$ & 1.74 & 212.60 & 6.08 & 74.00 & 0.92 & 430 & 287.30 & 8.22 \\
\hline ONYE-31 & $"$ & $"$ & $"$ & $"$ & 1.89 & 234.34 & 6.39 & 77.45 & 0.40 & 426 & 302.57 & 8.25 \\
\hline ONYE-32 & $"$ & $"$ & $"$ & $"$ & 1.53 & 188.25 & 6.19 & 65.40 & 1.11 & 429 & 287.84 & 9.46 \\
\hline ONYE-33 & $"$ & $"$ & $"$ & $"$ & 1.58 & 178.35 & 6.01 & 59.80 & 0.56 & 426 & 298.24 & 10.05 \\
\hline ONYE-34 & $"$ & $"$ & $"$ & $"$ & 1.56 & 187.32 & 6.86 & 69.95 & 0.69 & 428 & 267.79 & 9.81 \\
\hline ONYE-35 & $"$ & $"$ & $"$ & $"$ & 1.89 & 213.76 & 5.77 & 68.65 & 0.67 & 429 & 311.38 & 8.40 \\
\hline ONYE-36 & $"$ & $"$ & $"$ & $"$ & 1.88 & 202.66 & 7.19 & 77.80 & 0.68 & 426 & 260.49 & 9.24 \\
\hline ONYE-37 & $"$ & $"$ & $"$ & $"$ & 1.82 & 213.48 & 6.37 & 75.30 & 0.52 & 429 & 283.51 & 8.46 \\
\hline ONYE-38 & $"$ & $"$ & $"$ & $"$ & 1.46 & 177.29 & 6.07 & 62.45 & 0.69 & 428 & 283.89 & 9.72 \\
\hline ONYE-39 & $"$ & $"$ & $"$ & $"$ & 2.36 & 229.25 & 6.24 & 76.95 & 0.47 & 426 & 297.92 & 8.11 \\
\hline ONYE-40 & $"$ & $"$ & $"$ & $"$ & 2.17 & 217.96 & 6.55 & 77.55 & 0.67 & 426 & 281.06 & 8.45 \\
\hline ONYE-41 & $"$ & $"$ & $"$ & $"$ & 2.06 & 212.27 & 6.22 & 74.45 & 0.76 & 428 & 285.12 & 8.35 \\
\hline ONYE-42 & $"$ & $"$ & $"$ & $"$ & 2.08 & 210.29 & 6.20 & 72.10 & 0.72 & 427 & 291.66 & 8.60 \\
\hline ONYE-43 & $"$ & $"$ & $"$ & $"$ & 1.97 & 240.07 & 6.13 & 76.10 & 0.73 & 429 & 315.47 & 8.06 \\
\hline
\end{tabular}


huminite ( $>90$ vol.\%) prevail in the part of the Onyeama seam and indeed inertinite contents are generally low $(<20$ vol.\%) throughout these seams. The proportion of liptinite in coals from the four mines varies widely, with the largest concentration ( 26.70 vol.\%) occurring at the Okaba seam. The mineral matter content is generally low in all the studied coal seams, and ranges from less than 1 vol.\% to 3 vol.\%. Mineral constituents include framboidal pyrite, marcasite, quartz and clay minerals. The Onyeama coals yielded vitrinite reflectance values of $0.57-0.59 \% \mathrm{Rr}$; the Okpara coals of $0.55-0.59 \% \mathrm{Rr}$; the Ezimo coals of $0.48-0.55 \% \mathrm{Rr}$ (apart from one sample with a reflectance of $0.59 \% \mathrm{Rr}$ ); and the Okaba coals of $0.53-0.59 \% \operatorname{Rr}$ (Table 1).

\section{Organic Geochemistry}

Table 3 shows the selected samples for Rock-Eval 6 and organic petrography $\mathrm{S}_{1}$ ranges from 0.26 in ONYE to $3.52 \mathrm{mgHC} / \mathrm{g}$ rock in OKAB while $\mathrm{S}_{2}$ ranges from 124.94 in OKPA to $240.07 \mathrm{mgHC} / \mathrm{g}$ rock in ONYE. $\mathrm{HI}$ ranges from 183.21 in EZIM to $344.50 \mathrm{mgS}_{2} / \mathrm{g}$ TOC in ONYE and $\left(\mathrm{S}_{1}+\mathrm{S}_{2}\right) / \mathrm{g}$ TOC ranges from 126.28 OKPA to 242.04 in ONYE. However, $\mathrm{T}_{\max }$ value varies from $414^{\circ} \mathrm{C}$ in the Okaba seam to $432^{\circ} \mathrm{C}$ in the Onyeama seam. TOC value consequently varies from $62.35 \%$ in the Ezimo seam to $77.80 \%$ in the Onyeama seam. $\mathrm{S}_{1}+\mathrm{S}_{2}$ and $\mathrm{S}_{2} / \mathrm{S}_{3}$ value varies from $120.5 \mathrm{mg} \mathrm{HC} / \mathrm{g}$ rock in the Okpara seam to $242.04 \mathrm{mg} \mathrm{HC} / \mathrm{g}$ rock in the Onyeama seam and 6.2 in the Okpara seam to 39.2 in the Onyeama seam with mean values of 169.59 and 21.0 respectively.

Figure 8 shows the chromatogram of the saturate fraction of the coals. The $n$-alkane distribution is dominated by high molecular weight $n$-alkane, with maximum at $n$ - $\mathrm{C}_{29}$. Ratios calculated from

the chromatogram include a pristane (pr)/phytane $(\mathrm{ph})$ ratio of 7.93 and carbon preference index (CPI) of 3.11

(Table 4). Figure 9 shows the distribution of hopanes investigated at $\mathrm{m} / \mathrm{z} 191$ of the

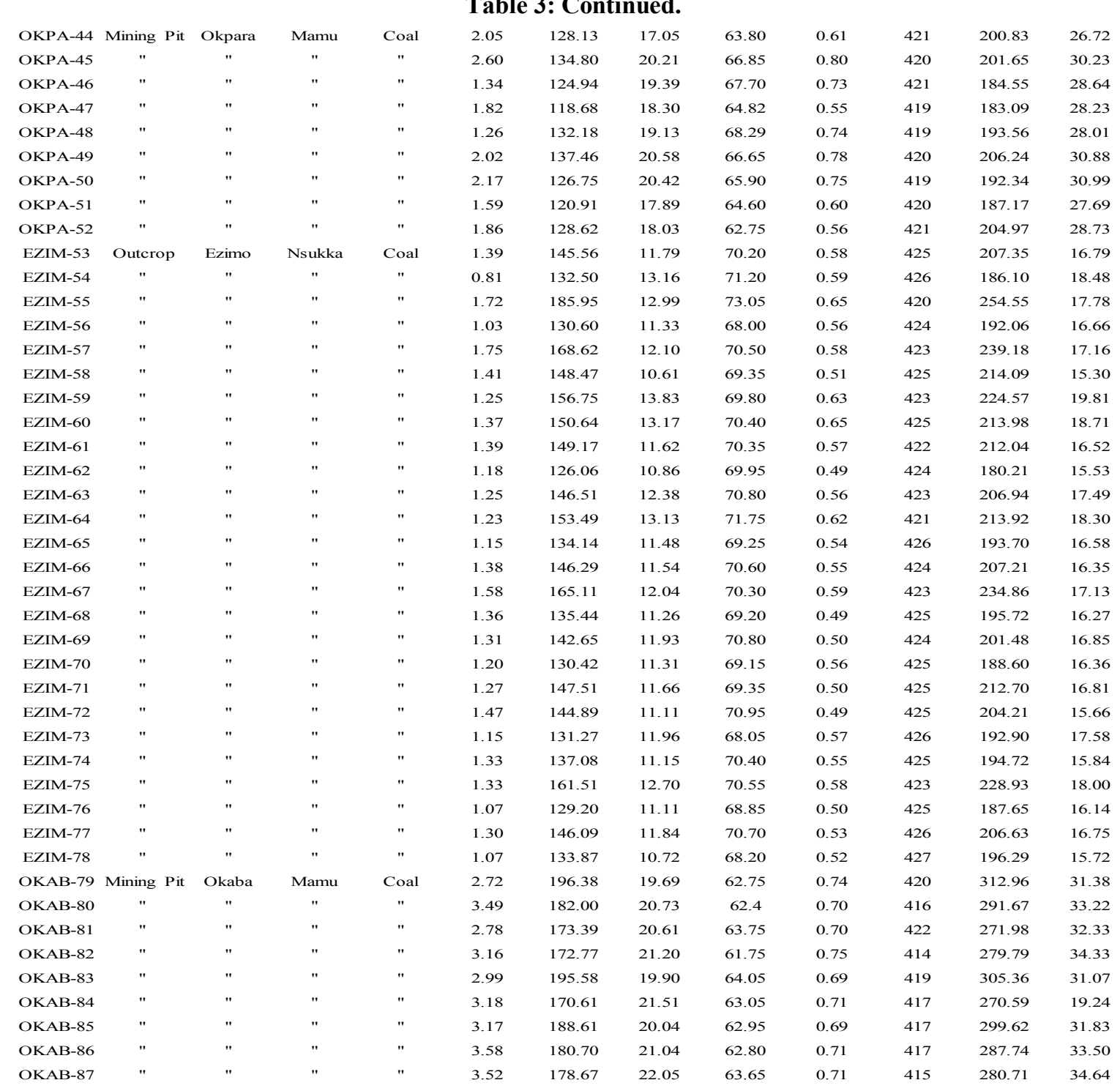


non-adduct fraction. The $17 \alpha \beta-\mathrm{C}_{30}$ hopane is dominant, and a step-like decrease in homohopanes up to $\mathrm{C}_{34}$. The ratio 0.85 of the geo-epimer to the sum of the geo and bio-epimers of homohopane $\left(\mathrm{C}_{31} \mathrm{~S} / \mathrm{S}+\mathrm{R}\right)$ is indicative of equilibrium and support the early maturity of this coal. The common

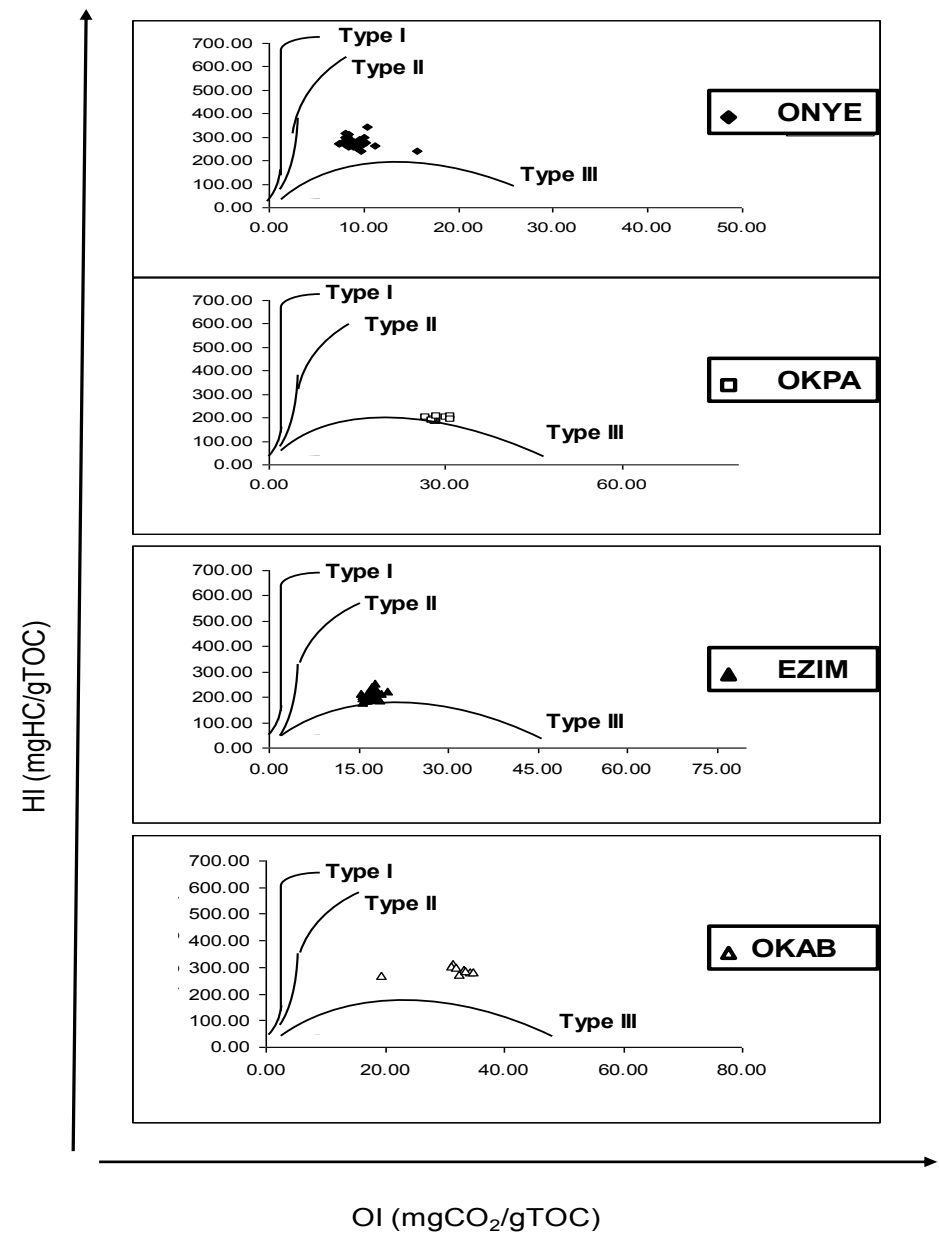

Fig. 7: HI versus OI plots of Cretaceous coal samples from the Anambra Basin.

redox proxy (pr/ph) is affected by source organism but its value of 7.93 also indicates major contribution from terrestrial higher plant. Long/Short $n$-alkanes and Odd over Even Preference (OEP) values varies from 3.4 in the Okaba seam to 63.60 in the Onyeama seam and 2.0 in the Onyeama seam to 6.8 in the Okpara seam with mean values of 25.58 and 3.23 respectively. These further support the high contribution of terrestrial organic matter to the source rock. 
Table 4: Triterpanes indices from GC-MS of the studied coal samples from the Anambra Basin.

\begin{tabular}{|c|c|c|c|c|c|c|c|c|c|c|c|c|}
\hline Sample & Sample & Locality & Lithology & Formation & $\mathbf{P r} / \mathbf{P h}$ & Long/Short & OEP & Pr/ & $\mathbf{P h} /$ & Ts/ & $\mathrm{C}_{31} /$ & CPI \\
\hline Name & Type & & & & Ratio & Ratio & & n-C17 & n-C18 & $(\mathrm{Ts}+\mathrm{Tm})$ & $\mathrm{C}_{31}+\mathrm{C}_{32}$ & \\
\hline ONYE-9 & Mining Pit & Onyeama & Coal & Mamu & 7.80 & 30.60 & 2.20 & 20.70 & 2.01 & 0.01 & 0.70 & 1.84 \\
\hline ONYE-23 & $"$ & $"$ & $"$ & $"$ & 9.60 & 14.70 & 2.40 & 24.50 & 1.20 & 0.01 & 0.72 & 1.82 \\
\hline ONYE-29 & $"$ & $"$ & $"$ & $"$ & 7.30 & 41.90 & 2.20 & 13.70 & 2.60 & 0.01 & 0.71 & 1.80 \\
\hline ONYE-34 & $"$ & $"$ & $"$ & $"$ & 8.10 & 25.20 & 2.20 & n.d & 2.15 & 0.01 & 0.68 & 1.75 \\
\hline ONYE-40 & $"$ & $"$ & $"$ & $"$ & 7.60 & 63.60 & 2.20 & n.d & 4.40 & 0.01 & 0.71 & 1.81 \\
\hline ONYE-43 & $"$ & $"$ & $"$ & $"$ & 8.00 & 38.90 & 2.00 & n.d & 2.70 & 0.01 & 0.73 & 3.64 \\
\hline OKPA-44 & Mining Pit & Okpara & Coal & Mamu & 8.50 & 19.00 & 4.40 & 17.50 & 0.80 & 0.05 & 0.93 & 4.49 \\
\hline OKPA-46 & $"$ & $"$ & $"$ & $"$ & 8.80 & 40.30 & 6.80 & 13.90 & 0.80 & 0.10 & 0.97 & 6.09 \\
\hline OKРA-49 & $"$ & $"$ & $"$ & $"$ & 6.00 & 26.70 & 5.00 & 16.00 & 1.14 & 0.09 & 0.94 & 4.60 \\
\hline EZIM-55 & Outcrop & Ezimo & Coal & Nsukka & 8.10 & 41.00 & 2.80 & 17.00 & 0.80 & 0.08 & 0.89 & 5.80 \\
\hline EZIM-62 & $"$ & $"$ & $"$ & $"$ & 6.90 & 19.10 & 3.00 & 23.20 & 1.30 & 0.06 & 0.87 & 2.56 \\
\hline EZIM-75 & $"$ & $"$ & $"$ & $"$ & 6.50 & 20.70 & 3.00 & n.d & 1.50 & 0.07 & 0.90 & 2.61 \\
\hline EZIM-77 & $"$ & $"$ & $"$ & $"$ & 7.40 & 16.00 & 3.00 & n.d & 1.20 & 0.06 & 0.88 & 2.58 \\
\hline OKAB-79 & Mining Pit & Okaba & Coal & Mamu & 9.00 & 3.90 & 3.70 & 5.20 & 0.21 & 0.04 & 1.00 & 2.07 \\
\hline OKAB-81 & $"$ & $"$ & $"$ & $"$ & 8.40 & 3.40 & 2.90 & 4.00 & 0.20 & 0.06 & 0.98 & 2.85 \\
\hline OKAB-87 & $"$ & $"$ & $"$ & $"$ & 8.90 & 4.20 & 3.90 & 4.90 & 0.20 & 0.06 & 0.99 & 3.43 \\
\hline
\end{tabular}

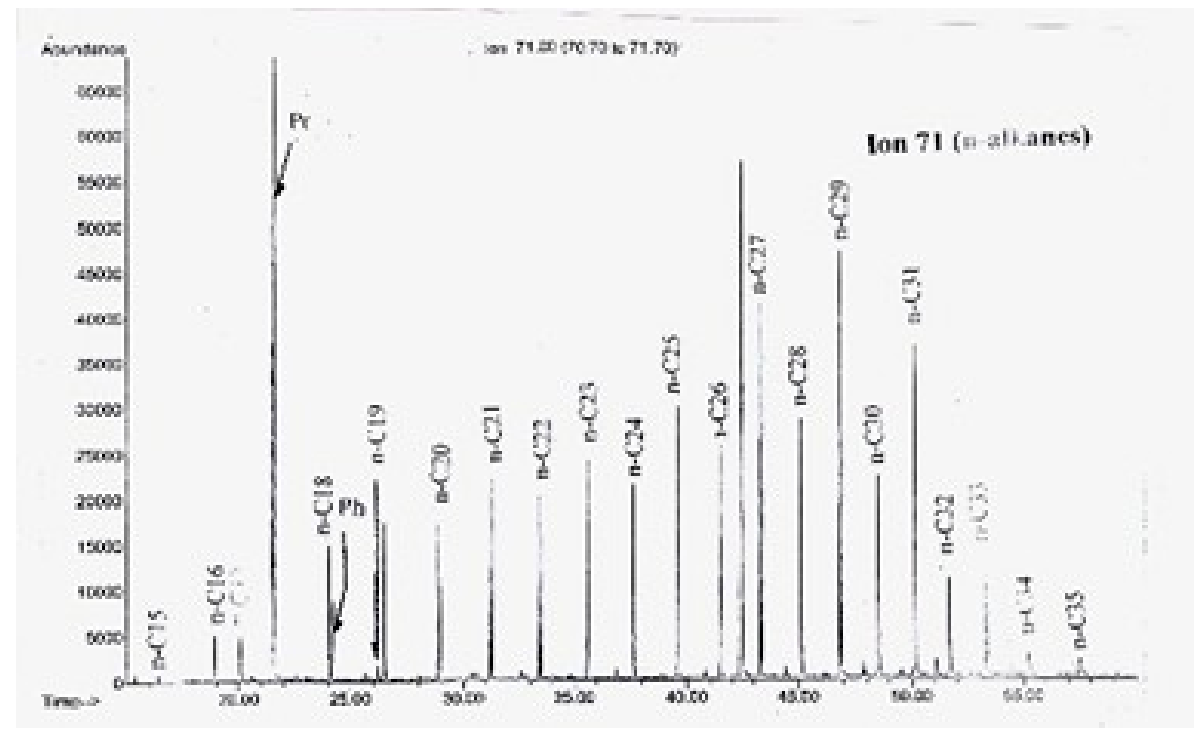

Fig. 8: Gas chromatogram of the saturate fraction, with the dominant n-alkane, pristine (pr) and phytane (ph) labeled. 


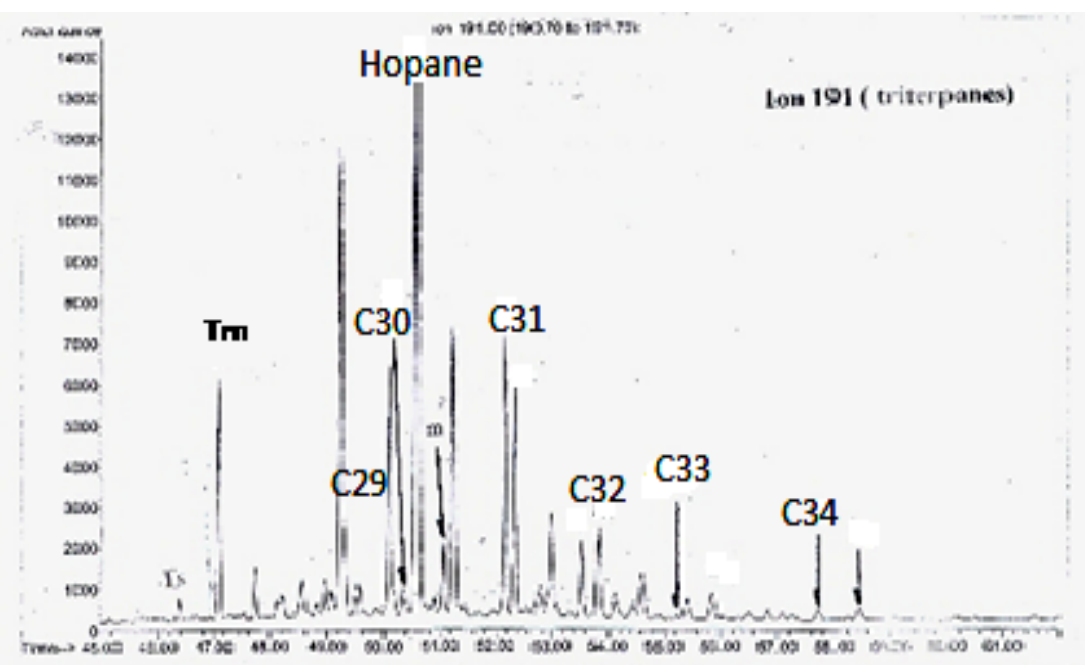

Fig. 9: Mass fragmentogram of the non-adduct fraction, showing distribution of hopane at m/z 191 .

\section{Kerogen Types}

\section{Discussion}

The average maceral composition (Fig. 6) based on the average percentages of huminite-liptinite inertinite (H:L:I) ratios are: 79:10:9 for the Onyeama coals, 62:16:21 for the Ezimo coals, 47:16:37 for the Okpara coals and 50:18:32 for the Okaba coals. This indicates a predominance of huminite (Type III kerogen) with contributions of inertinite (Type IV kerogen) and liptinite (Type II kerogen) in the organic matter.

\section{Rock-Eval 6 Pyrolysis}

Rock Eval 6 pyrolysis data are shown in Table 3 and plots of the coals as kerogen type are shown in Fig. 7. All of the samples have Hydrogen Indices (HI) on the order expected for oil and gas prone humic coals, although the oxygen indices are lower than expected for normal humic coals. Based on the Mukhopadyay and Hatcher (1993) classification of kerogen in coals relative to HI and OI, all of the samples plot between Types II and III, or within the mixinitic field, where desmocollinite (collodetrinite) is associated with liptinites as a good potential for the generation of oil/gas (Uzoegbu, 2010). This type of coal facies is considered to have enhanced liquid petroleum generative potential (Mukhopadyay and Hatcher, 1993); a minimum content of 15-20\% liptinite is considered to be the threshold for a coal to be considered as a potential petroleum source rock (Hunt, 1991; Fowler et al., 1991). Plots on the modified Van Krevelen diagram for samples from the Maastrichtian coals show a mixied range of type II and type III organic matter, with dominance of type II (Figs. 7). However, the location of the highest HI samples could be assigned to a high-potential type III kerogen at the diagenesis/catagenesis boundary (Obaje et al., 2004). This backed up by the nonoccurrence of notable type I organic matter in the petrographic (maceral) facies (Fig. 6). $\mathrm{S}_{1}$ values are relatively low for coals of this rank and composition (Sykes and Snowdon, 2002). The cause of these low values is not known but may be due to expulsion or oxidation which can reduce $\mathrm{S}_{1}$ by up to $50 \%$ (e.g. Sykes and Dow, 2001).

The gas-prone nature of this rock rules out Type II kerogen, which usually shows $\mathrm{S}_{2} / \mathrm{S}_{3}$ greater than 5 , while the maturity from vitrinite reflectance as well as $\mathrm{T}_{\max }$ suggest that the current $\mathrm{HI}$ results from thermal evolution of a Type III kerogen, with initial HI between $600 \mathrm{mgHC} \mathrm{g}^{-1} \mathrm{TOC}$ and $850 \mathrm{mgHC} \mathrm{g}^{-1} \mathrm{TOC}$ (Lafargue et al., 1998). High TOC contents (as much as $67.21 \mathrm{wt} \%$ ) and HI between 183.09 and $344.53 \mathrm{mg} \mathrm{HC} / \mathrm{g}$ TOC characterize the coal beds of the Mamu and Nsukka Formations. 


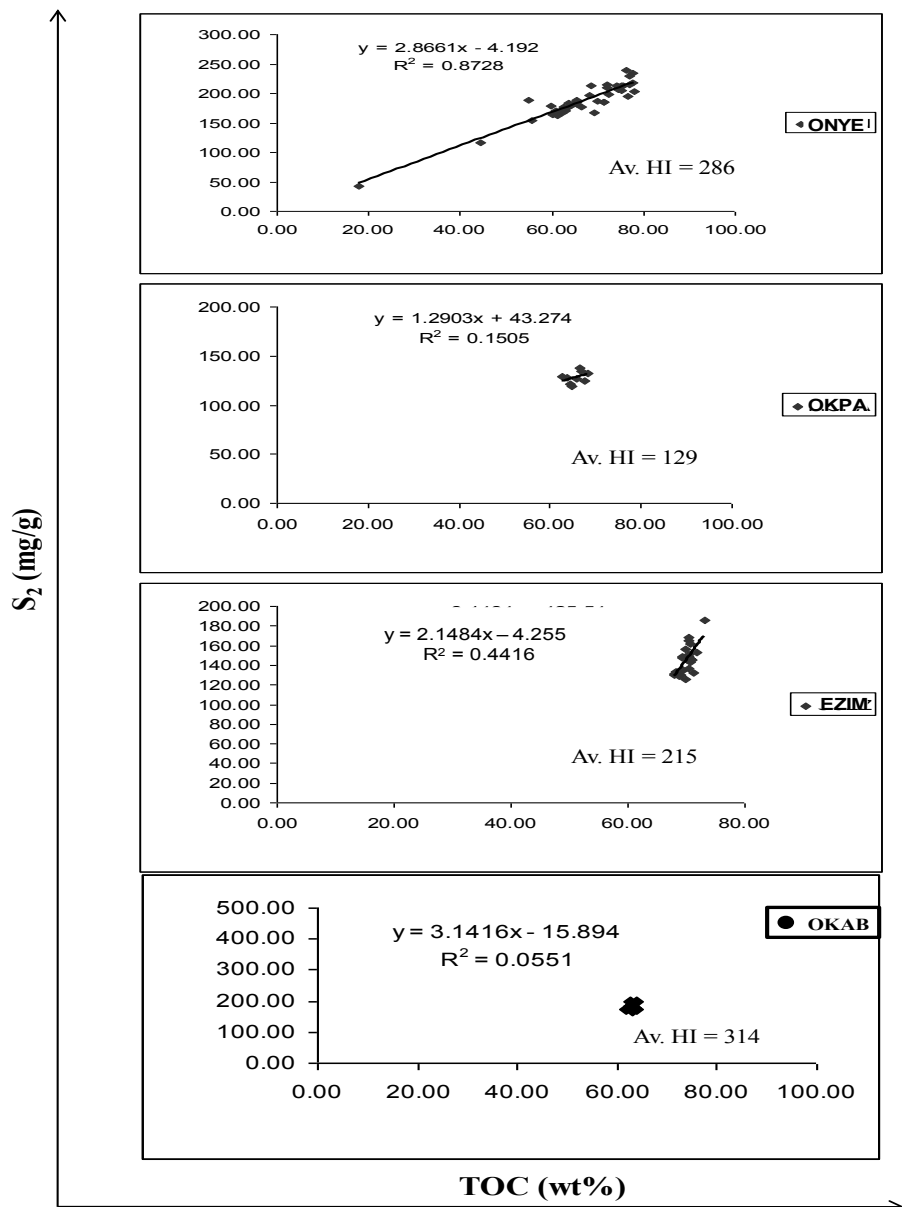

\section{Fig. 10: $S_{2}$ vs. TOC plots of coal samples from the Anambra Basin with calculated average hydrogen indices (Av. HI), sample name indicated).}

The regression equation based on the $S_{2}$ vs. TOC diagrams gave an average HI values of 286, 129, 215 and 314 mg HC/g TOC for Mamu and Nsukka coals (Figs. 10). A plot of $\mathrm{S}_{2}$ vs. TOC and determining the regression equation has been used by Langford and Blanc-Valleron (1990) as the best method for determining the true average $\mathrm{HI}$ and measuring the adsorption of hydrocarbons by rock matrix. The $\mathrm{T}_{\max }$ and vittrinite reflectance values obtained on the coals indicate immature to early mature stages (early oil window) for the successions in the Anambra Basin. Peters (1986) has suggested that at a thermal maturity equivalent to vitrinite reflectance of $0.6 \%\left(\mathrm{~T}_{\max } 435^{\circ} \mathrm{C}\right)$, rocks with $\mathrm{HI}$ above $300 \mathrm{mg} \mathrm{HC} / \mathrm{g}$ TOC produce oil, those with HI between 300 and 150 produce oil and gas, those with HI less than 50 are inert. However, Sykes and Snowdon (2002) are of the opinion that coaly source rocks are sufficiently different from marine and lacustrine source rocks in their organic matter characteristics to warrant separate guidelines for their assessment based on Rock-Eval pyrolysis. Based on the study of some New Zealand coals, they concluded that the rank threshold for oil generation in coals is indicated at $\mathrm{T}_{\max } 420-430^{\circ} \mathrm{C}\left(\mathrm{R}_{\mathrm{o}} 0.55-0.6 \%\right)$ and the threshold for oil expulsion at $\mathrm{T}_{\max } 430-440^{\circ} \mathrm{C}\left(\mathrm{R}_{\mathrm{o}}\right.$ $0.65-0.85 \%)$.

A corresponding plot on the HI- $\mathrm{T}_{\max }$ diagram based on the values given by Peters (1986) indicates an oil and gas generative potential for some of the samples from the Maastrichtian coals (Fig. 11).

On the selected samples for Rock-Eval 6 and organic petrography $\mathrm{S}_{1}$ ranges from 0.26 in ONYE to $3.52 \mathrm{mgHC} / \mathrm{g}$ rock in $\mathrm{OKAB}$ while $\mathrm{S}_{2}$ ranges from 124.94 in OKPA to $240.07 \mathrm{mgHC} / \mathrm{g}$ rock in 


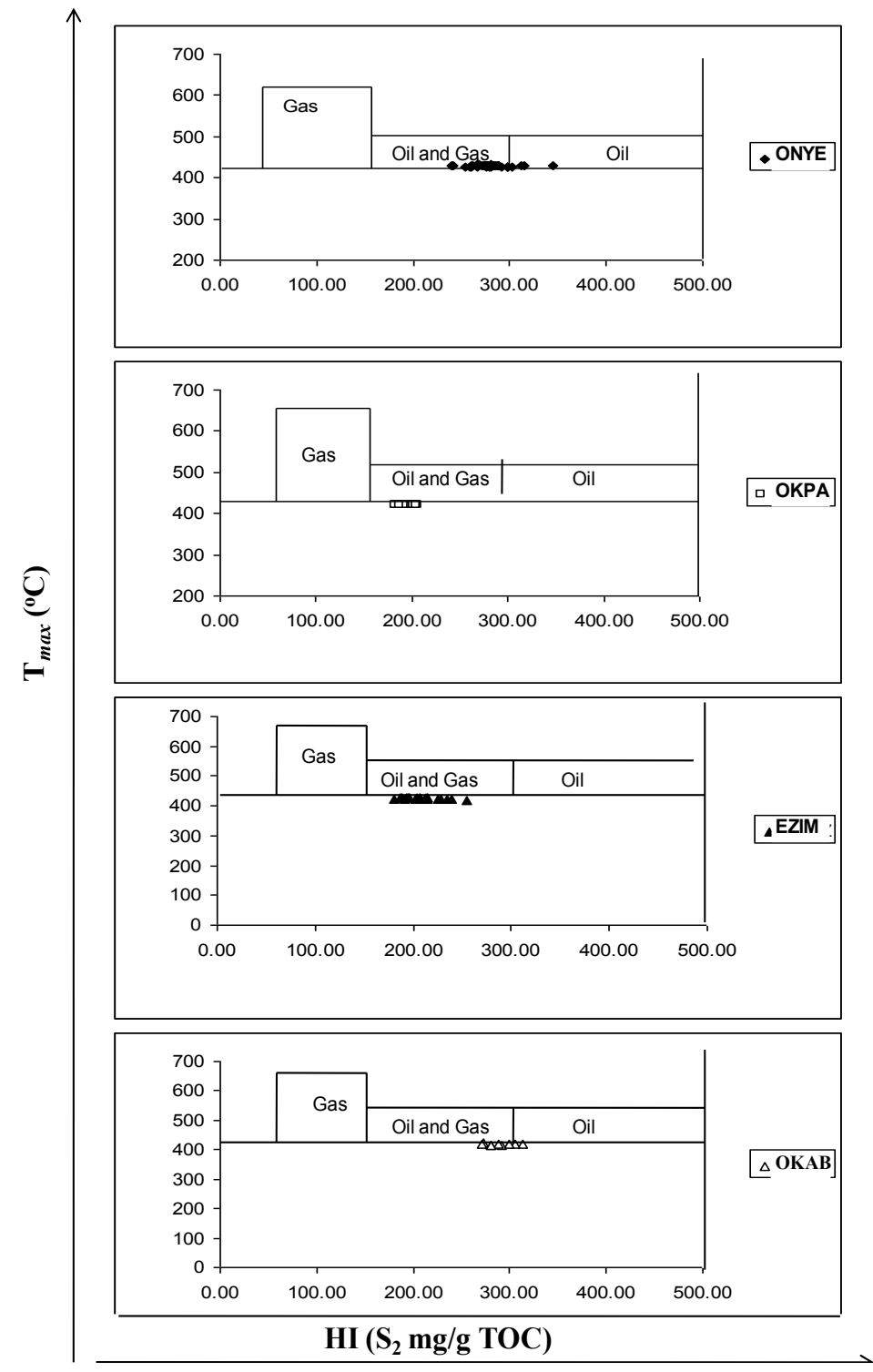

Fig. 11: $T_{\max }$ vs. HI plots of coal samples from the Anambra Basin (sample name attached).

ONYE. HI ranges from 180.21 in EZIM to $344.50 \mathrm{mgS} 2 / \mathrm{gTOC}$ in ONYE and (S1+S2)/gTOC ranges from 126.28 OKPA to 242.04 in ONYE. Vitrinite reflectance $\left(\% \mathrm{R}_{\mathrm{o}}\right)$ ranges from 0.48 in EZIM to 0.59 in ONYE. These parameters $\left[\mathrm{S}_{1}, \mathrm{~S}_{2}, \mathrm{HI}\right.$ and $\left.\left(\mathrm{S}_{1}+\mathrm{S}_{2}\right) / \mathrm{gTOC}\right]$ were plotted relative to $\% \mathrm{R}_{0}$ (Figs. 12-13).

Figs. 12-13 shows the peaks to plateaus exhibited in these plots for $\mathrm{S}_{1}, \mathrm{~S}_{2}, \mathrm{HI}$ and $\left(\mathrm{S}_{1}+\mathrm{S}_{2}\right) / \mathrm{gTOC}$ at $0.58 \% \mathrm{R}_{\mathrm{o}}$ for $\mathrm{HI}$, and between $0.53,0.56$ and $0.60 \% \mathrm{R}_{\mathrm{o}}$ for $\mathrm{S}_{1}, \mathrm{~S}_{2}$ and $\left(\mathrm{S}_{1}+\mathrm{S}_{2}\right) / \mathrm{gTOC}$ indicating the level of maturity and areas of hydrocarbon generation potential from $\% R_{0}$. The peaks further shows that areas below $\% R_{0}$ of 0.55 will have low yield of hydrocarbon consequently have low expulsion rate. Larger data sets have been used by Sykes and Snowdon (2002) and Petersen (2002). 

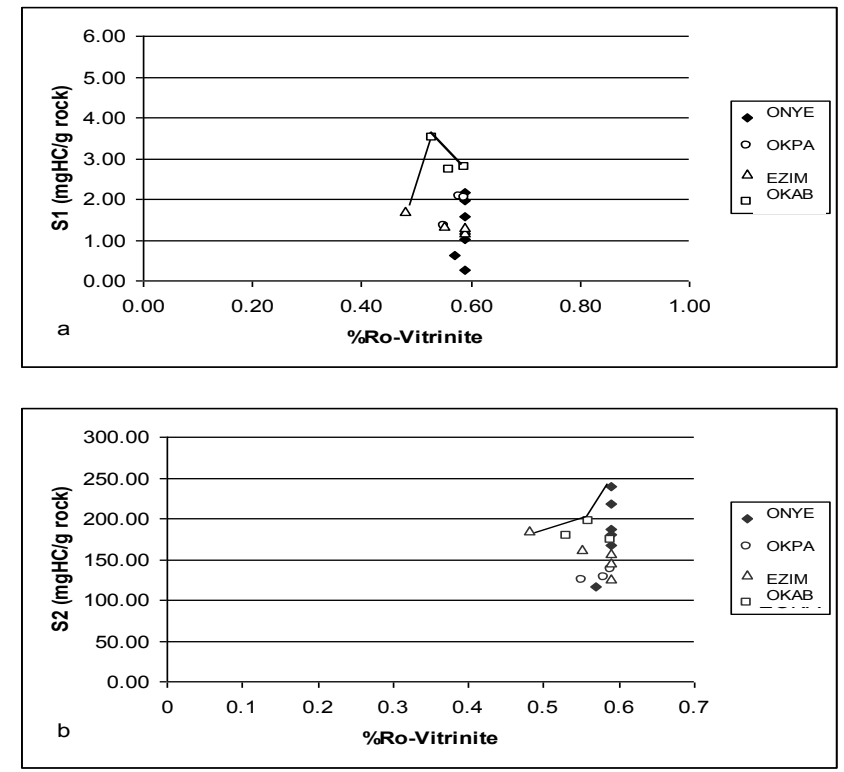

Fig. 12: (a) $S_{1}$ (mgHC/g rock) versus vitrinite $\% R_{0}$; (b) $S_{2}\left(m g H C / g\right.$ rock) versus vitrinite $\% R_{0}$.

Similar peaks in Rock-Eval 6 parameters relative to $\mathrm{T}_{\max }$ or vitrinite $\% \mathrm{R}_{\mathrm{o}}$ have been noted previously in coals by Pittion and Gouadain (1985; $\mathrm{S}_{1} / \mathrm{TOC}$ peak $\sim 1.0 \%$ Ro, $\mathrm{T}_{\max } \sim 450^{\circ} \mathrm{C}$ ), Suggate and Boudou (1993; HI peak at $\mathrm{T}_{\max }$ $\sim 440^{\circ} \mathrm{C}$ and $\left.\sim 0.80 \% \mathrm{R}_{0}\right)$, Boreham et al. (1999; HI peak at $\mathrm{T}_{\max } \sim 440^{\circ} \mathrm{C}$ and $\left.\sim 0.80 \% \mathrm{R}_{0}\right)$, Petersen $2002 ; \mathrm{S}_{2}$ and $\mathrm{S}_{1}$ at $0.85 \% \mathrm{R}_{0}, \mathrm{HI}$ at $0.90 \% \mathrm{R}_{0}$ ), and Stasiuk et al. $\left(2006\right.$; HI peak $\sim 0.90 \% \mathrm{R}_{0}$; between 0.90 and $1.0 \% \mathrm{R}_{\mathrm{o}}$ for peaks $\mathrm{S}_{2}$ and $\mathrm{S}_{1}+\mathrm{S}_{2} / \mathrm{TOC}$ ). The peaks in these coals indicates that hydrocarbon generation potential increases with increasing rank, but further work is required to assess the hydrocarbon potential of the coals from these areas.
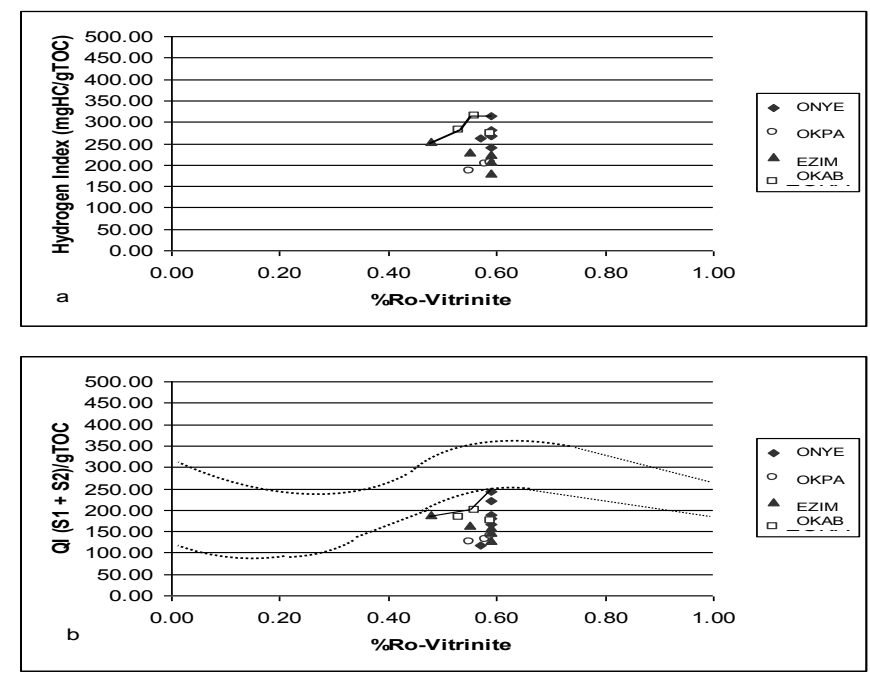

Fig. 13: (a) Hydrogen Index $\left(\mathrm{S}_{2} / \mathrm{TOC} x \mathrm{x} 100\right)$ versus vitrinite $\% \mathrm{R}_{0}$; (b) Quality Index $\left[\left(\mathrm{mgHC} / \mathrm{g}\right.\right.$ TOC; $\left.\left(\mathrm{S}_{1}+\mathrm{S}_{2}\right) / \mathrm{TOC} \times 100\right]$ versus vitrinite $\% \mathrm{R}_{0}$. Dashed lines are trend of "hydrocarbon generation" for New Zealand coals from Sykes and Snowdon (2002) (these authors used the Suggate Index of Coalification instead of $\% \mathrm{R}_{\mathrm{o}}$ vitrinite). 
In agreement with the petrographic composition, the $\mathrm{HI}$ versus OI diagram classifies the coals as containing an abundance of Type III kerogen (Fig. 7). Also, atomic $\mathrm{H} / \mathrm{C}$ ratios of $0.80-0.90$ and $\mathrm{O} / \mathrm{C}$ ratios of $0.11-0.17$ show that the coals generally plot in the upper part of the Type III band on a van Krevelen diagram. However, despite the fact that bulk geochemical analyses classify the coals as dominated by Type III kerogen, the petrographic analyses have demonstrated the presence of relatively large amounts of liptinite, such as sporinite and cutinite, in the coals. Although humic coals dominated by huminite have proven to be oil-prone (e.g. Petersen, 2006; Petersen and Nytoft, 2006), the liptinite macerals are more paraffinic in structure and they are likely to be more oil-prone than the huminite. This is favourable for the oil-proneness of the coals, as the oil expulsion efficiency is dependent on the coals' ability to generate long-chain aliphatics $\left(>\mathrm{C}_{20-25}\right)$ (Isaksen et al., 1998).

Gas chromatography and gas chromatography-mass spectrometry analyses of the lipid extracts reported biomarkers with a dominance of long-chain $n$-alkanes $\left(\mathrm{C}_{24}-\mathrm{C}_{31}\right)$ with obvious odd-over-even predominance (Fig. 8). This points to high inputs of terrestrial humic/higher plants organic matter as well as maturity levels below the conventional beginning of oil generation $\left(R_{0} 0.6 \%\right)$. Pristane/phytane ratios from 6.50 to 9.60 confirm a considerable input of terrestrial organic matter and high levels of aerobic conditions. The low $18 \alpha(\mathrm{H})$ trisnorneohopanes $/ 17 \alpha(\mathrm{H})$-trisnorhopanes $\left(\mathrm{T}_{\mathrm{s}} / \mathrm{T}_{\mathrm{m}}\right)$ and relatively high moretanes $/ 17 \alpha(\mathrm{H}) 21 \beta(\mathrm{H})$-hopanes $(\mathrm{m} / \alpha \beta \mathrm{H})$ ratios indicate maturity below the conventional beginning of oil generation (Waples and Machihara, 1991). With increasing maturity, $17 \alpha(\mathrm{H})$-trisnorhopanes $\left(\mathrm{T}_{\mathrm{m}}\right)$ normally transform to $18 \alpha(\mathrm{H})$-trisnorneohopanes $\left(\mathrm{T}_{\mathrm{s}}\right)$ and moretanes $(\mathrm{m})$ to $17 \alpha(\mathrm{H}) 21 \beta(\mathrm{H})$-hopanes $(\alpha \beta \mathrm{H})$ (Meyers and Snowdon, 1993). However, the trend observed in this study shows that the Ts is dependent on the lithology and is generally suppressed in the coals compared to shales of the same vitrinite reflectance maturity (Obaje et al., 2004). 18 $\alpha(\mathrm{H})$-trisnorneohopanes does not appear in the coaly facies until a vitrinite reflectance maturity of about $0.7 \%\left(\mathrm{R}_{0}\right)$ is attained, whereas in the shales the $T_{s}$ begins to appear already as early as $R_{o}$ maturity of about $0.5 \%$.

\section{Thermal maturity and coal rank}

The average $\mathrm{T}_{\max }$ values of the Onyeama, Okpara, Ezimo and Okaba coals are $428^{\circ} \mathrm{C}, 420^{\circ} \mathrm{C}, 424^{\circ} \mathrm{C}$ and $418^{\circ} \mathrm{C}$, respectively. This implies that the Onyeama coals are slightly more mature than the coals from the other three localities. Vitrinite reflectance values support this; the average vitrinite reflectance value of the Onyeama coals is $0.59 \% \mathrm{Rr}$, whereas the Okpara coals had an average reflectance value of $0.57 \% \mathrm{Rr}$ while Ezimo and the Okaba coals have an average values of 0.58 and $0.56 \% \mathrm{Rr}$ respectively. Hopane ratios, however, are consistent with the $\mathrm{T}_{\max }$ and vitrinite reflectance values, as the Onyeama coals have lower hopane $\mathrm{C}_{31} \mathrm{~S} /(\mathrm{S}+\mathrm{R})$ ratios $(0.71)$ than the Okpara, Ezimo and Okaba $(0.95,0.90,0.99)$ coals (Table 4). The Okpara, Ezimo and Okaba coals are thus thermally immature with regard to petroleum generation, whereas the Onyeama coals are immature to potentially marginally mature. Espitalié and Bordenave (1993) established threshold values for various types of kerogens $\mathrm{T}_{\max }$ for the beginning of the oil and gas windows. The CPI of 3.11 supports the early maturity indices discussed above, though this parameter is usually high in marine source rocks that produce mostly high molecular weight hydrocarbons (Peters and Moldowan, 1993). For Type III kerogen, the onset of hydrocarbon generation occurs at a $\mathrm{T}_{\max }$ value of $435^{\circ} \mathrm{C}$. According to the $\mathrm{T}_{\max }$ - vitrinite reflectance relationship established for humic coals by Petersen (2006), this corresponds to $\sim 0.73 \%$ Rr. Sykes (2001), Sykes and Snowdon (2002) and Petersen $(2002,2006)$ have shown that in humic coals a time-lag exists between the onset of petroleum generation and the onset of efficient oil expulsion at the start of the effective oil window (the "oil expulsion window"). Although petroleum generation in humic coals starts at $0.5-0.6 \% \mathrm{Rr}$, the lowest maturity at which efficient expulsion may occur were determined to be around $0.65 \% \mathrm{Rr}$ for Cenozoic coals (Petersen, 2006). Most coals start to expel at higher maturities. The high content of oil-prone aliphatic kerogen, such as cutinite, in some of the Mamu Formation coals may, however, generate hydrocarbons earlier than the vitrinitic kerogen and may in addition facilitate saturation of hydrocarbons to the expulsion threshold at lower maturities than "pure" humic coals (Akande et al., 2007).

\section{Petroleum generation potential}

The $\mathrm{S}_{1}$ and $\mathrm{S}_{2}$ yields for the studied coals are $0.93-3.58 \mathrm{mg} \mathrm{HC} / \mathrm{g}$ rock and 116.41-240.07 mg HC/g rock, respectively, and the total generation potential $\left(\mathrm{S}_{1}+\mathrm{S}_{2}\right)$ ranges from 169.59 to $242.04 \mathrm{mg} \mathrm{HC} / \mathrm{g}$ rock. This is within the "normal" range for coals, implying that the coals have the potential to generate gas and oil. Source rock quality, as indicated by the plot of $\mathrm{S}_{2}$ against TOC,

shows that the studied coals are prolific source rocks for the generation of oil (Fig. 14). On a regional scale, the studied coals are suggested to be more prolific than the coals in the Middle 


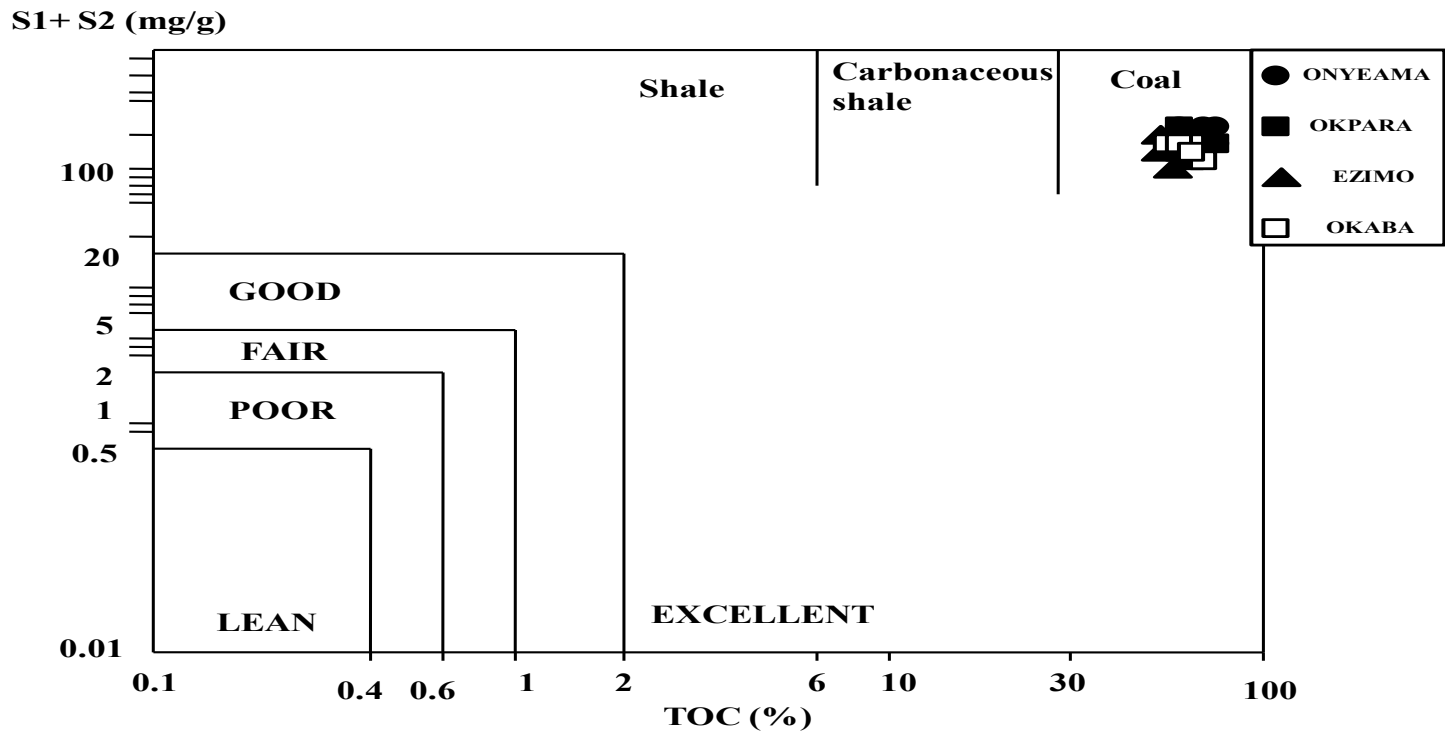

Fig. 14: Source rock quality information on the basis of $S_{2}$ yields ( $\mathrm{kg} \mathrm{HC} / \mathrm{t} \mathrm{rock}$ ) versus TOC (wt \%) for the Onyeama, Okpara, Ezimo and Okaba coals. Note that this classification of the coals as a prolific hydrocarbon source rock is consistent with the $\mathrm{HI}$ interpretation. (Modified after Burwood et al., 1995).

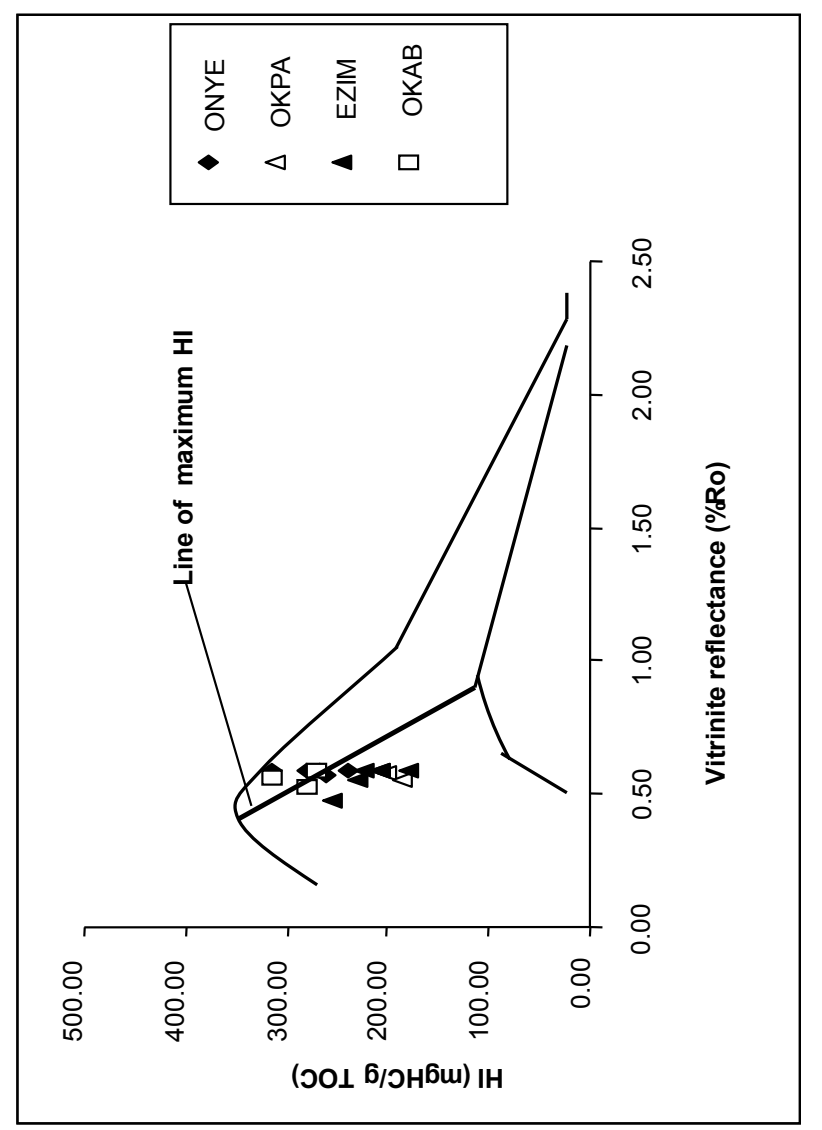

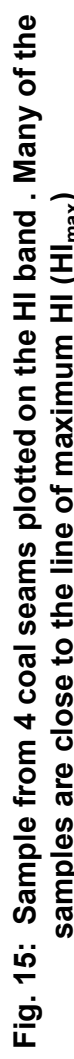


Benue Trough, which are essentially gas-prone with some potential for mixed oil- and gas-generation (Obaje and Hamza, 2000). The HI values range from 183.09 to $344.53 \mathrm{mg} \mathrm{HC} / \mathrm{g}$ TOC, which also indicate the potential to generate mixed oil and gas (Fig. 15). It should, however, be noted that for immature coals the $\mathrm{HI}$ increases up to a maximum value $\left(\mathrm{HI}_{\max }\right.$ ) during initial maturation (Teichmüller and Durand, 1983; Sykes, 2001; Sykes and Snowdon, 2002; Petersen, 2006). $\mathrm{HI}_{\max }$ is a better estimate of the true generation potential of a coal. By translation of the measured $\mathrm{HI}$ values to the $\mathrm{HI}_{\max }$-line defined from a worldwide coal data-set (Petersen, 2006), the Mamu and Nsukka Formations coals have $\mathrm{HI}_{\max }$ values ranging from 235 to $350 \mathrm{mg} \mathrm{HC} / \mathrm{g}$ TOC (Fig. 15). It is now accepted that humic coals, particularly those of Cenozoic age, have the potential to generate and expel liquid hydrocarbons (Petersen, 2006; Petersen and Nytoft, 2006). However, it is also evident that the presence of high proportions of oil-prone, aliphatic organic matter in the coals will increase their capability to generate oil. Hunt (1991) and Hendrix et al. (1995) suggested that if coals are to have the capacity to generate and expel oil, they must contain at least 15-20 vol.\% liptinite prior to catagenesis and have a corresponding HI value of at least $200 \mathrm{mg} \mathrm{HC} / \mathrm{g}$ TOC. Using these criteria, the studied Onyeama, Okpara, Ezimo and Okaba coals with an average of $\sim 16$ vol.\% liptinite and $\mathrm{HI}$ values $>200 \mathrm{mg} \mathrm{HC} / \mathrm{g}$ TOC would be able to generate oil. The high proportion of long-chain aliphatics in the range $\mathrm{C}_{24-31}$ in the Onyeama, Okpara, Ezimo and Okaba coals emphasizes their ability to generate oil.

\section{Potential Petroleum Systems}

The buildup of any prospect or of a petroleum system requires the availability of good-quality source rocks. Additionally, the stratigraphic position of the source rocks, the availability of good-quality reservoir and seal lithologies, timing of hydrocarbon generation, favourable regional migration pathways, and trapping mechanisms must also be considered. Anambra basin has the best natural petroleum system in terms of formational source rock, reservoir, and seal lithologies. Apart from interbedded marine sandstone facies in the Nkporo/Enugu shales, petroleum generated from the Nkporo/Enugu shale and Mamu coal source rocks have good reservoirs in the overlying clean quartz arenites of the Ajali sandstone. Sandstones of the Mamu Formation could provide additional reservoirs. The overlying shales of the Imo and Nsukka formations are expected to provide regional seal for hydrocarbon that may have been generated and migrated into reservoirs in this part of the Benue trough. Because the intense Santonian deformation had occurred prior to the deposition of sediments and hydrocarbon generation in this basin, only the well documented abrupt facies changes would likely provide stratigraphic traps for hydrocarbon accumulations in this basin. However, local Cenozoic tectonics could also have enhanced the formation of some structural traps (Obaje et al., 2004).

\section{Conclusions}

Coals from the Maastrichtian Mamu and Nsukka Formations in the Anambra Basin, SE Nigeria, are of sub-bituminous rank. With regard to petroleum generation, coals from the Okpara, Ezimo and Okaba mines are thermally immature, whereas coals from Onyeama are thermally immature to marginally mature. The coals are dominated by huminite, and are classified as Type III kerogen both by Rock-Eval and elemental (atomic $\mathrm{H} / \mathrm{C}$ and $\mathrm{O} / \mathrm{C}$ ) ratios. Coal ranks range from a low of $0.56 \% \mathrm{R}_{\mathrm{o}}$ at Okaba to a high of $0.59 \% \mathrm{R}_{\mathrm{o}}$ in the Onyeama area. As well as, $\mathrm{T}_{\max }\left({ }^{\circ} \mathrm{C}\right)$ values increase with increasing vitrinite $\% \mathrm{R}_{\mathrm{o}}$ values. The classification of kerogen in these coal samples relative to HI and OI, of all the samples falls between type II and type III or within the mixinitic field with good potential for the generation of oil/gas. However, they may contain significant proportions of liptinite. $\mathrm{HI}_{\max }$ values range from 235 to $350 \mathrm{mg} \mathrm{HC} / \mathrm{g}$ TOC suggesting potential for both oil and gas generation. This is confirmed by a significant proportion of long-chain aliphatics in the range $\mathrm{C}_{24-31}$ in the coal matrix. Some indicators, such as $\% \mathrm{R}_{\mathrm{o}}$ and $\mathrm{T}_{\max }$ consistently indicate an immature to onset of maturity and early to beginning oil expulsion. If thermally mature, the coals could constitute good gas and oil source rocks, and mature equivalents in the Anambra Basin are important elements of the Cretaceous petroleum system in the basin. They may also represent possible source rocks beneath the Tertiary Niger Delta.

\section{Acknowledgement}

German Academic Exchange Services (DAAD) provided support and access to Organic Geochemistry/Organic Petrography laboratory facilities in Hannover, Germany. Dr. Hermann Wehner, George Scheeder and Jolanta Kus are thanked for supervision and generating data for this manuscript.

\section{References}

[1]. Agagu, O.K. (1978). Geology and petroleum potentials of Santonian to Maastrichtian sediments in the Anambra basin, Eastern Nigerian. Ph.D Thesis, University of Ibadan.

[2]. Akande, S.O., Hoffinecht, A. and Erdtmann, B.D. (1992). Upper Cretaceous and Tertiary coals from southern Nigeria: Composition, rank, depositional environments, and other their technological properties. NAPE Bull., 7, 26-38.

[3]. Akande, S.O., Ogunmoyero, I.B., Petersen, H.I. and Nytoft, H.P. (2007). Source rock evaluation of coals from the Lower Maastrichtian Mamu Formation, SE Nigeria. Jour. Petrol. Geol., 30(4), 303-324. 
[4]. Allen, J.R.L. (1965). Late Quaternary Niger delta and adjacent areas - sedimentary environments and lithofacies. AAPG Bull., 49, 547-600.

[5]. Boreham, C.J., Horsfield, B. and Schenk, H.J. (1999). Predicting quantities of oil and gas generated from Australian Permian coals, Bowen Basin using pyrolytic techniques. Marine and Petroleum Geology, 16, 165-188.

[6]. Burwood, R., De Witte, S.M., Mycke, B. and Paulet, J. (1995). Petroleum geochemical characterization of the Lower Congo Coastal basin, Bucomazi Formation. In: Katz, B.J. (Ed.) Petroleum source rocks. Springer Verlag, Berlin, 235-263.

[7]. Bustin, R.M. (1988). Sedimentology and characteristics of dispersed organic matter in Tertiary Niger delta: origin of source rocks in a deltaic environment. AAPG Bull., 72, 277-298.

[8]. Ekweozor, C.M. and Daukoru, E.M. (1994). Northern delta depobelt portion of the Akata-Agbada (!) Petroleum System, Niger Delta, Nigeria. In: Magoon, L.B., Dow, W.G. (Eds.), The petroleum system - from source to trap. AAPG Memoir, 60, 599-613.

[9]. Eneogwe, C. and Ekundayo, O. (2003). Geochemical correlation of crude oils in the NW Niger Delta, Nigeria. Journ. Petrol. Geol., 26, 95-103.

[10]. Espitalié, J. and Bordenave, M.L. (1993). Rock-Eval pyrolysis. In: Bordenave, M.L. (ed.), Applied Geochemistry. Éditions Technip, Paris, 237-261.

[11]. Fowler, M.G., Goodarzi, F., Gentzis, T. and Brooks, P.W. (1991). Hydrocarbon potential of Middle and Upper Devonian coals from Meville Island, Arctic Canada. Organic Geochemistry, 17, 681-699.

[12]. Hendrix, M.S., Brassel, S.C., Currol, A.R. and Graham, S.A. (1995). Sedimentology, Organic geochemistry and petroleum potential of Jurassic coal measures, Tarim, Junggar and Turpan Basins, North west China. AAPG Bull., 79, 929-959.

[13]. Hogue, M. (1977). Petrographic differentiation of tectonically controlled Cretaceous sedimentary cycles, south eastern Nigeria. Sed. Geol., 17, 235-245.

[14]. Hunt, J.M. (1991). Generation of gas and oil from coal and other terrestrial organic matter. Organic Geochemistry, 17, 673-680.

[15]. Isaksen, G.H., Curry, D.J., Yeakel, J. D., and Jenssen, A. I. (1998). Controls on the oil and gas potential of humic coals. Organic Geochemistry 29, 23-44.

[16]. Ladipo, K.O. (1988). Paleogeography, sedimentation and tectonics of the Upper Cretaceous Anambra Basin, SE Nigeria. Journal African Earth Science, 7, 865-871.

[17]. Lafargue, E. Marquis, F. and Pillot, D. (1998). Rock- Eval 6 applications in hydrocarbon exploration, production, and soil contamination studies. Renue de L'Inst. Fr. Petrole, 53(4), 421-437.

[18]. Langford, F. F. and Blanc- Valleron, M. M. (1990). Interpreting Rock-Eval pyrolysis data using graphs of pyrolyzable hydrocarbons vs Total Organic Carbon. Amer. Assoc. Petrol. Geol. Bull., 74(6), 799-804.

[19]. Meyers, P.A. and Snowdon, L.R. (1993). Type and maturity of organic matter accumulation during Early Cretaceous subsidence of the Ex-Mouth plateau, northwest Australian margin. Amer. Assoc. Petrol. Geol. Studies in Geology, 37, 119-130.

[20]. Mukhopadhyay, P.G. and Hatcher, P.G. (1993). Composition of coal. pp. 93-118. In: Law, B.E. and Rice, D.D. (Ed.): Hydrocarbons from Coal. AAPG Studies in Geology, 38.

[21]. Obaje N. G. and Hamza, H. (2000), Liquid hydrocarbon source rock. Potential of mid-Cretaceous coals and coal measures in the Middle Benue Trough of Nigeria. Intern. Jour. Earth Sci., 89, 130-139.

[22]. Obaje, N.G., Wehner, H., Scheeder, G., Abubakar, M.B. and Jauro, A. (2004). Hydrocarbon prospectivity of Nigerian's inland basins: From the viewpoint of organic geochemistry and organic petrology. AAPG Bull., 88(3), 325-353.

[23]. Orajaka, I.P., Onwemesi, G., Egboka, B.C.E and Nwankor, G.I. (1990). Nigerian Coal. Mining Mag., 162, $446-451$.

[24]. Peters, K. E. (1986), Guidelines for evaluating petroleum source rocks using programmed pyrolysis. Amer. Assoc. Petrol. Geol. Bull., 70, 318-329.

[25]. Peters, K. E. and Moldowan, J. M. (1993), The biomarker guide; Interpreting molecular fossils in petroleum and ancient sediments. Prentice-Hall, Englewood Cliffs, New Jersey.

[26]. Petersen, H.I. (2002). A reconsideration of the "oil window" for humic coal and kerogen Type III. Journal Petroleum Geology, 25, 407-432.

[27]. Petersen, H.I., 2006. The petroleum generation potential and effective oil window of humic coals related to coal composition and age. Int. J. Coal Geol., 67, 221-248.

[28]. Petersen, H.I. and Nytoft, H.P. (2006). Oil generation capacity of coals as a function of coal age and aliphatic structure. Org. Geochem., 37, 558-583.

[29]. Pittion, J.L. and Gouadain, J. (1985). Maturity studies of the Jurassic'coal unit' in three wells from the Haltenbanken area. Petroleum Geochemistry in Exploration of the Norwegian Shelf. Graham and Totman, London, 205-211.

[30]. Reyment, R.A., 1965. Aspect of the geology of Nigeria. University of Ibadan press. $145 \mathrm{pp}$.

[31]. Short, K.C and Stauble, A.J. 1967. Outline of geology of Niger delta. AAPG. Bull., 51, 761-779.

[32]. Simpsons, A., 1954. The geology of parts of Onitsha, Owerri, and the Nigerian coal fields. Geol. Surv. Nigeria Bull., 24, 121pp.

[33]. Stasiuk, L.D., Galarza, F. and Bagheri-Sadeghi, H. (2006). Petrology, rank and evidence for petroleum generation, upper Triassic to Middle Jurassic coals, central Alborz Region, Northern Iran. International Journal Coal Geology, 67, 249-258.

[34]. Suggate, R.P. and Boudou, J.P. (1993). Coal rank and type variations I Rock-Eval assessment of New Zealand coals. Journal Petroleum Geology, 16, 73-88.

[35]. Sykes, R. (2001). Depositional and rank controls on the petroleum potential of coaly source rocks. In: Hill, K. C., Bernecker, T. (Eds.): Eastern Australasian Basins Symposium, a Refocused Energy Perspective for the Future. Petrol. Expl. Soc. Australia Spec. Publ., 591-601.

[36]. Sykes, R. and Dow, D.J. (2001). Petroleum source rock potential of North Cap Formation (Late Cretaceous) coaly sediments, Taranaki Basin, New Zealand. Petroleum Conference Proceedings, March 19-22, 2000, 264-286.

[37]. Sykes, R. and Snowdon, L.R. (2002). Guidelines for assessing the petroleum potential of coaly source rocks using Rock-Eval Pyrolysis. Organic Geochemistry, 33, 1441-1455.

[38]. Taylor, G.H., Teichmüller, M., Davis, A., Diessel, C.F.K., Littke, R. and Robert, P. (1998). Organic Petrology. Gebrüder Bornträeger, Berlin, 25-502.

[39]. Teichmüller, R. and Durand, B. (1983), Fluorescence microscopic rank studies on liptinites and vitrinites in peat and coal, and comparison with results of the Rock- Eval Pyrolysis. Intern. Jour. Coal Geol., 2, 197-230.

[40]. Uzoegbu, M.U. (2010). Technological properties and hydrocarbon generative potential of Late Cretaceous coal deposits in the Anambra Basin, Nigeria. Unpublished Ph.D thesis, Abubakar Tafawa Balewa University, Bauchi.

[41]. Waples, D. W. and Machihara, T. (1991), Biomarkers for geologists. A practical guide to the application of steranes and triterpanes in petroleum geology. Amer. Assoc. Petrol. Geol., Methods in Exploration, 9, 91pp. 